Supporting Information

for

\title{
Coupling of N-Heterocyclic Carbenes to Terminal Alkynes at Half Sandwich Cobalt NHC Complexes
}

\author{
Katharina Lubitz and Udo Radius*
}

Institut für Anorganische Chemie, Julius-Maximilians-Universität Würzburg, Am Hubland, 97074

Würzburg, Germany.

Corresponding author E-Mail address:

u.radius@uni-wuerzburg.de 


\section{1) Additional X-ray structures}

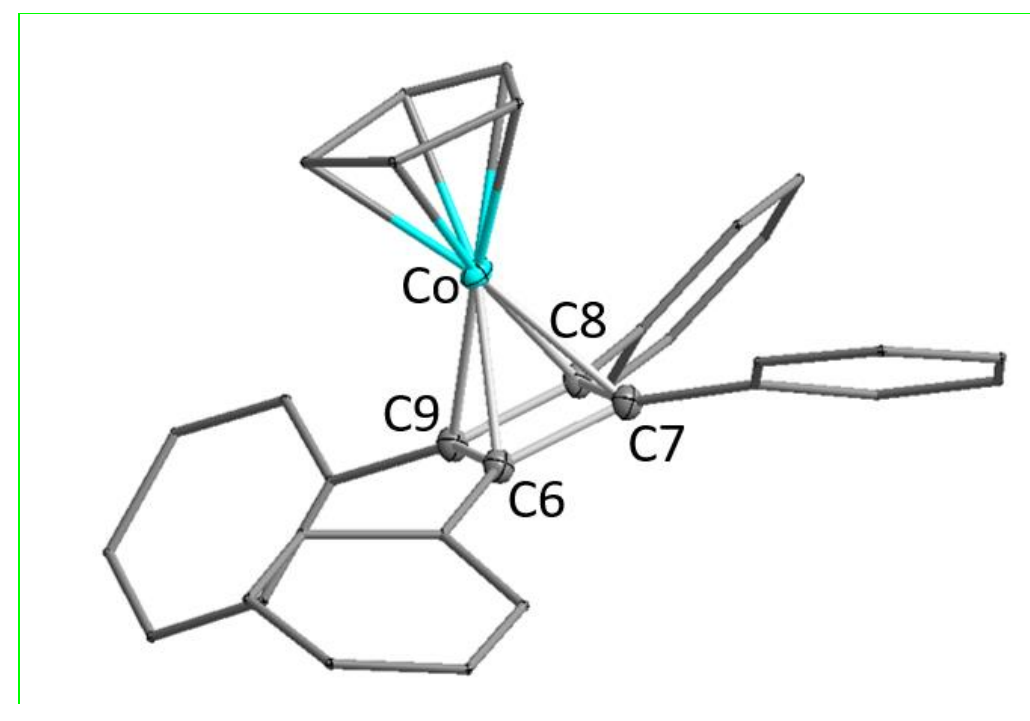

Figure S1: Molecular structure of $\left[\left(\eta^{5}-\mathrm{C}_{5} \mathrm{H}_{5}\right) \mathrm{Co}\left(\eta^{4}-\mathrm{C}_{4} \mathrm{Ph}_{4}\right)\right](5)$ in the solid sta te (ellipsoids set at the $50 \%$ probability level). Hydrogen atoms have been omitted for clarity. Selected bond length $[\AA]$ ] and angles $\left[^{\circ}\right]$ in 5 Co-C6 1.977(7), Co-C7 1.983(7), Co-C8 1.974(7), Co-C9 1.976(7), Co-( $\eta^{4}-$ $\left.\left.\mathrm{C}_{4} \mathrm{Ph}_{4}\right)_{\text {centroid }} 1.6852(7), \mathrm{Co}-\left(\eta^{5}-\mathrm{C}_{5} \mathrm{H}_{5}\right)_{\text {centroid }} 1.6670(7), \mathrm{C} 6-\mathrm{C} 71.441(10), \mathrm{C} 7-\mathrm{C} 81.464(7), \mathrm{C} 8-\mathrm{C} 91.458(9), \mathrm{C} 9-\mathrm{C} 61.466(8) ; \eta^{5}-\mathrm{C}_{5} \mathrm{H}_{5}\right)_{\text {Centroid }}-\mathrm{Co}-\left(\eta^{4}-\right.$ $\left.\mathrm{C}_{4} \mathrm{Ph}_{4}\right)_{\text {Centroid }} 178.652(49), \mathrm{C} 6-\mathrm{C} 7-\mathrm{C} 891.2(6), \mathrm{C} 7-\mathrm{C} 8-\mathrm{C} 988.9(6), \mathrm{C} 8-\mathrm{C} 9-\mathrm{C} 6$ 89.4(6), C9-C6-C7 90.(6).

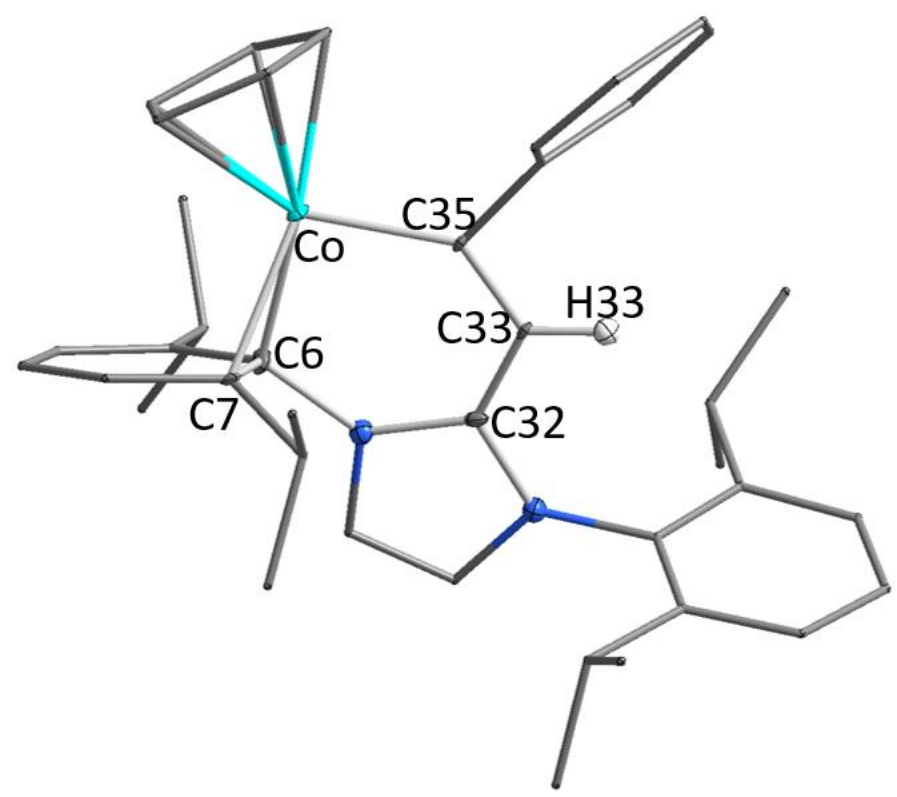

Figure S2: Preliminary molecular structure of $\left[\left(\eta^{5}-\mathrm{C}_{5} \mathrm{H}_{5}\right) \mathrm{Co}\left(-\mathrm{C}\{\mathrm{Ph}\}=\mathrm{C}\{\mathrm{H}\}\left\{\mathrm{Dipp} \mathrm{p}_{2} \mathrm{Im}\right\}\right)\right](6)$ in the solid state. 


\section{2) NMR/IR/UV-Vis Spectra of Complexes (2-9)}

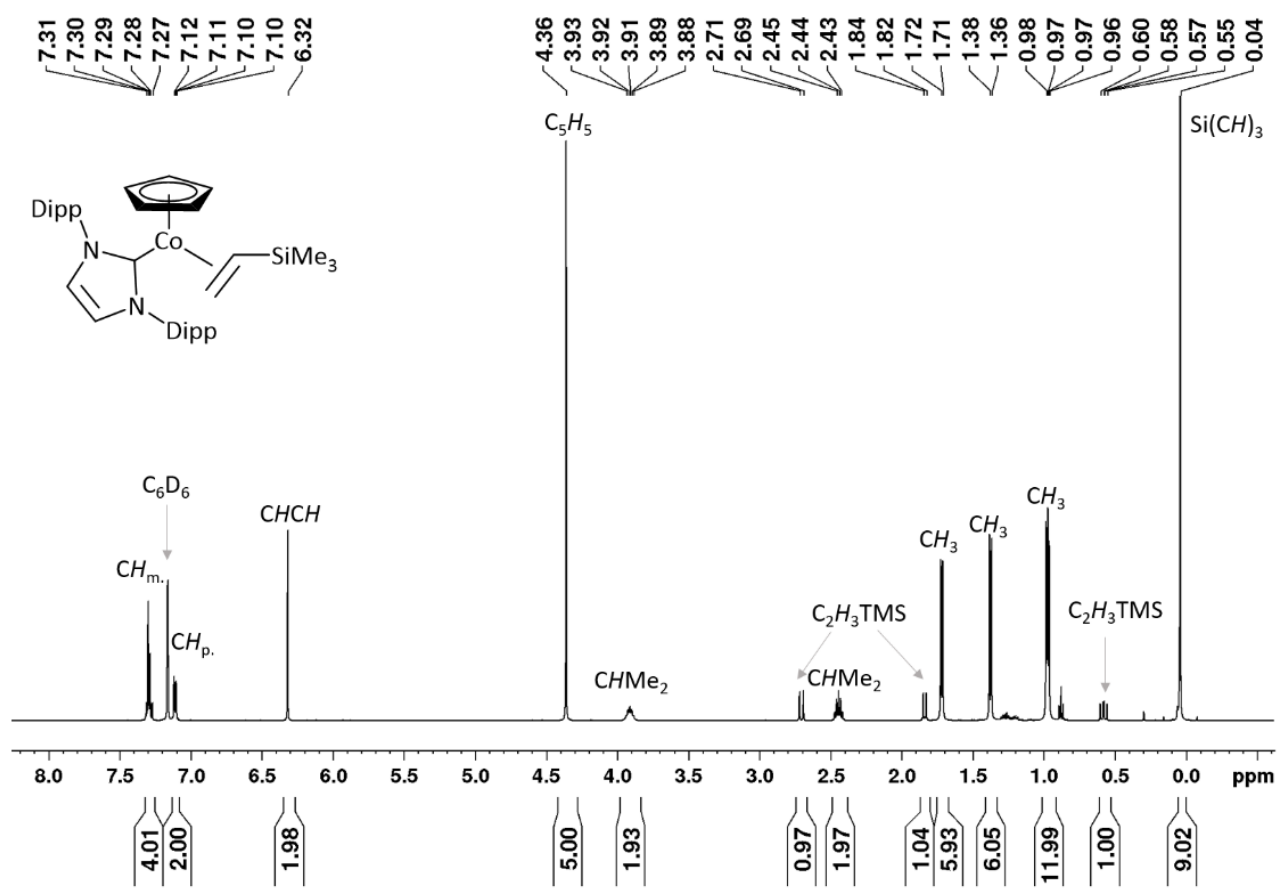

Figure S3: ${ }^{1} \mathrm{H}$ NMR spectrum of $\left[\left(\eta^{5}-\mathrm{C}_{5} \mathrm{H}_{5}\right) \mathrm{Co}\left(\mathrm{Dipp}_{2} \mathrm{Im}\right)\left(\eta^{2}-\mathrm{C}_{2} \mathrm{H}_{3} \mathrm{SiMe}_{3}\right)\right](2)$ in $\mathrm{C}_{6} \mathrm{D}_{6}$.

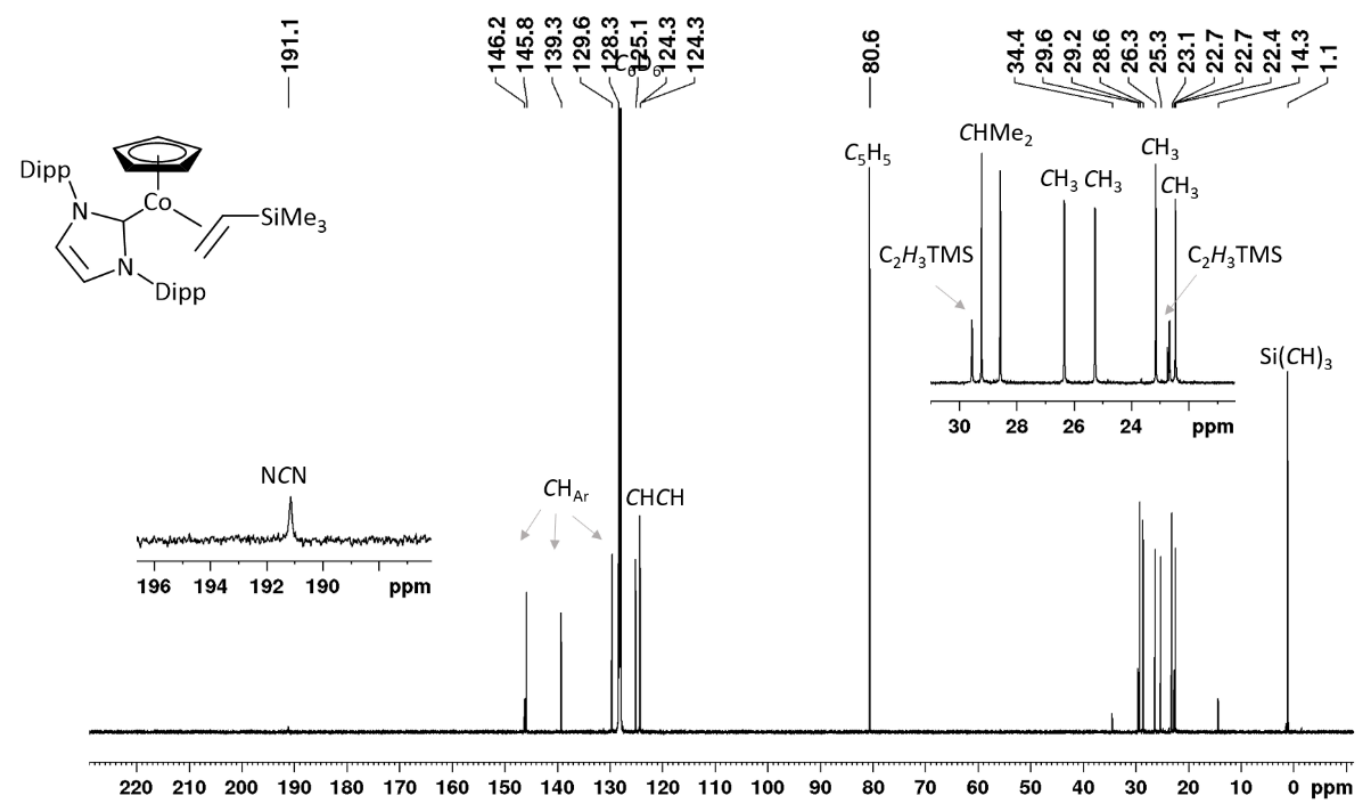

Figure S4: ${ }^{13} \mathrm{C}\left\{{ }^{1} \mathrm{H}\right\}$ NMR spectrum of $\left[\left(\eta^{5}-\mathrm{C}_{5} \mathrm{H}_{5}\right) \mathrm{Co}\left(\mathrm{Dipp}_{2} \mathrm{Im}\right)\left(\eta^{2}-\mathrm{C}_{2} \mathrm{H}_{3} \mathrm{SiMe} \mathrm{Me}_{3}\right)\right](2)$ in $\mathrm{C}_{6} \mathrm{D}_{6}$. 

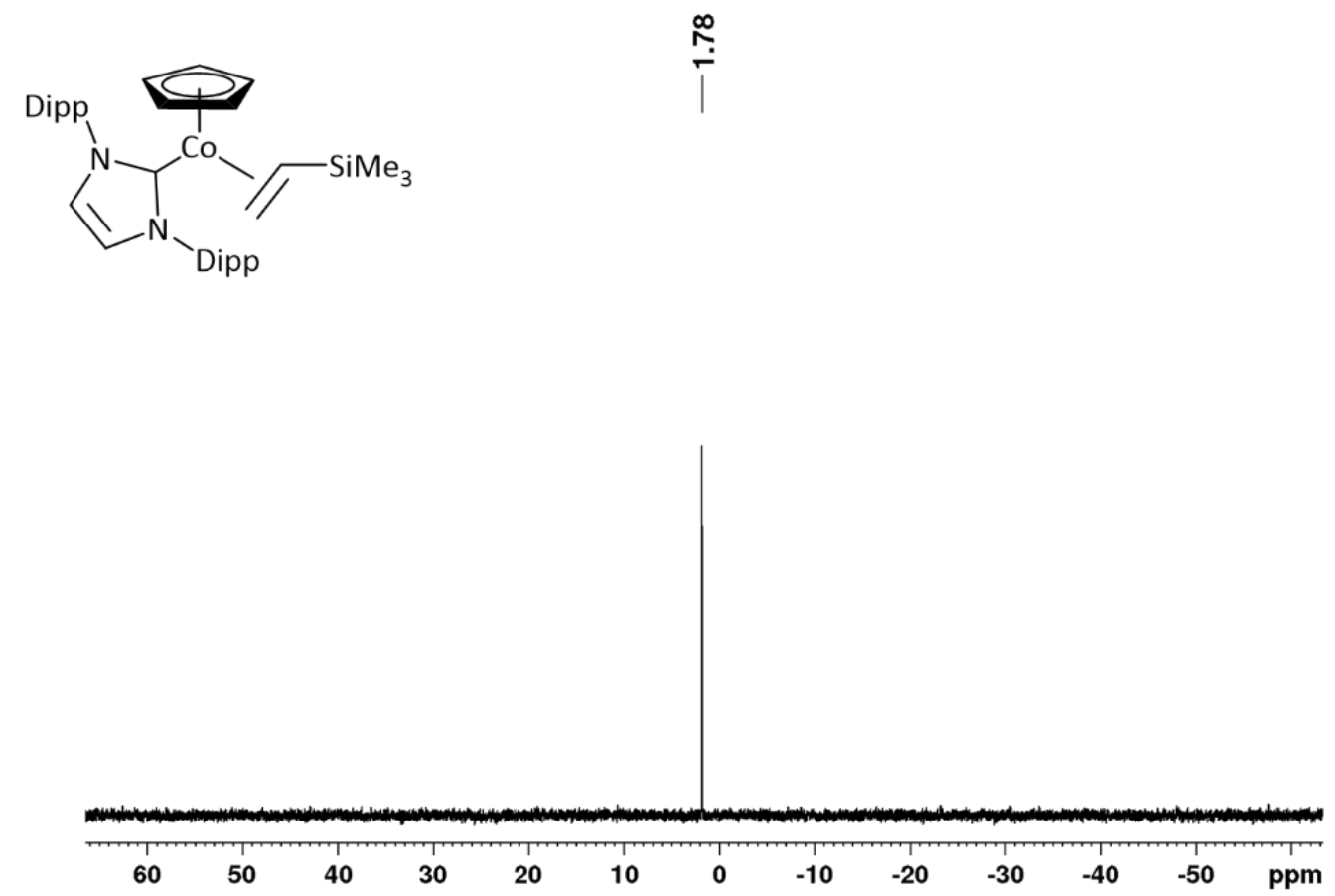

Figure S5: ${ }^{29} \mathrm{Si}$ NMR spectrum of $\left[\left(\eta^{5}-\mathrm{C}_{5} \mathrm{H}_{5}\right) \mathrm{Co}\left(\mathrm{Dipp}_{2} \mathrm{Im}\right)\left(\eta^{2}-\mathrm{C}_{2} \mathrm{H}_{3} \mathrm{SiMe}_{3}\right)\right](2)$ in $\mathrm{C}_{6} \mathrm{D}_{6}$.

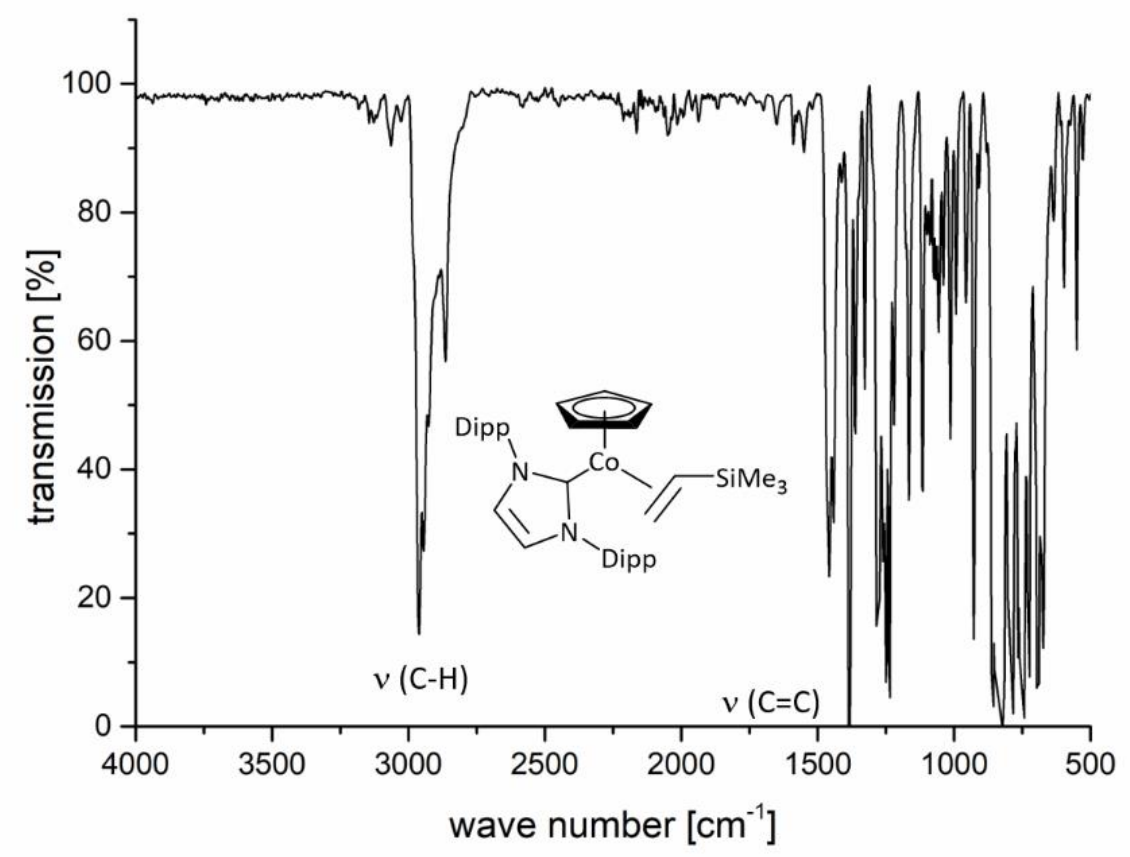

Figure S6: IR spectrum of $\left[\left(\eta^{5}-\mathrm{C}_{5} \mathrm{H}_{5}\right) \mathrm{Co}\left(\operatorname{Dipp}_{2} \mathrm{Im}\right)\left(\eta^{2}-\mathrm{C}_{2} \mathrm{H}_{3} \mathrm{SiMe}_{3}\right)\right]$ (2). 


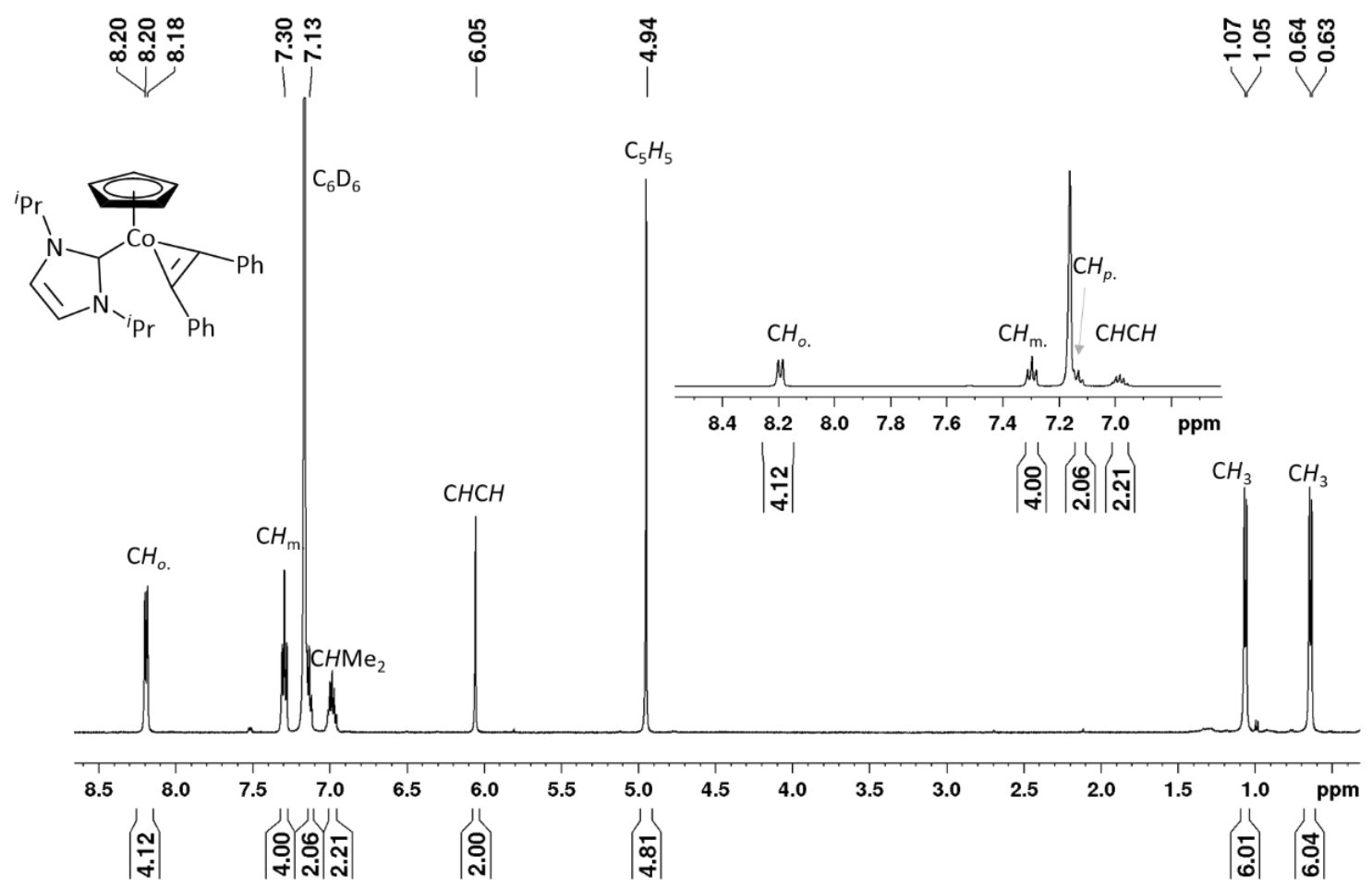

Figure S7: ${ }^{1} \mathrm{H}$ NMR spectrum of $\left[\left(\eta^{5}-\mathrm{C}_{5} \mathrm{H}_{5}\right) \mathrm{Co}\left({ }^{i} \mathrm{Pr}_{2} \mathrm{Im}\right)\left(\eta^{2}-\mathrm{C}_{2} \mathrm{Ph}_{2}\right)\right](3)$ in $\mathrm{C}_{6} \mathrm{D}_{6}$.<smiles>CCCN1C=CN(CCC)C1COc1ccccc1</smiles>
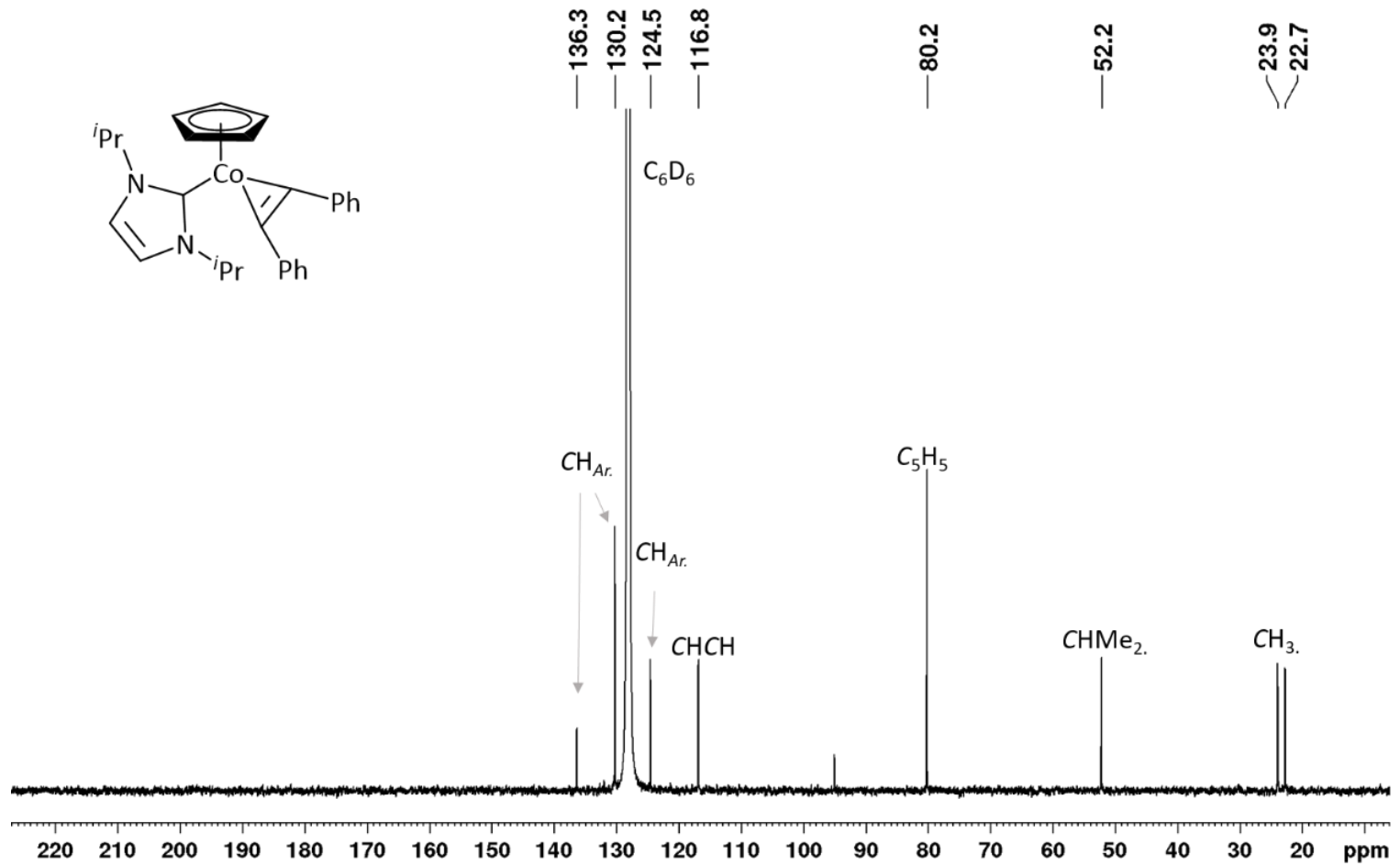

Figure S8: ${ }^{13} \mathrm{C}\left\{{ }^{1} \mathrm{H}\right\}$ NMR spectrum of $\left[\left(\eta^{5}-\mathrm{C}_{5} \mathrm{H}_{5}\right) \mathrm{Co}\left({ }^{i} \mathrm{Pr}_{2} \mathrm{Im}\right)\left(\eta^{2}-\mathrm{C}_{2} \mathrm{Ph}_{2}\right)\right](3)$ in $\mathrm{C}_{6} \mathrm{D}_{6}$. The resonances of the carbene carbon atom $(183.0 \mathrm{ppm})$ and the alkyne carbon atoms $(129.4 \mathrm{ppm})$ have been identified in a ${ }^{13} \mathrm{C}\left\{{ }^{1} \mathrm{H}\right\} \mathrm{HMBC}$ experiment. 


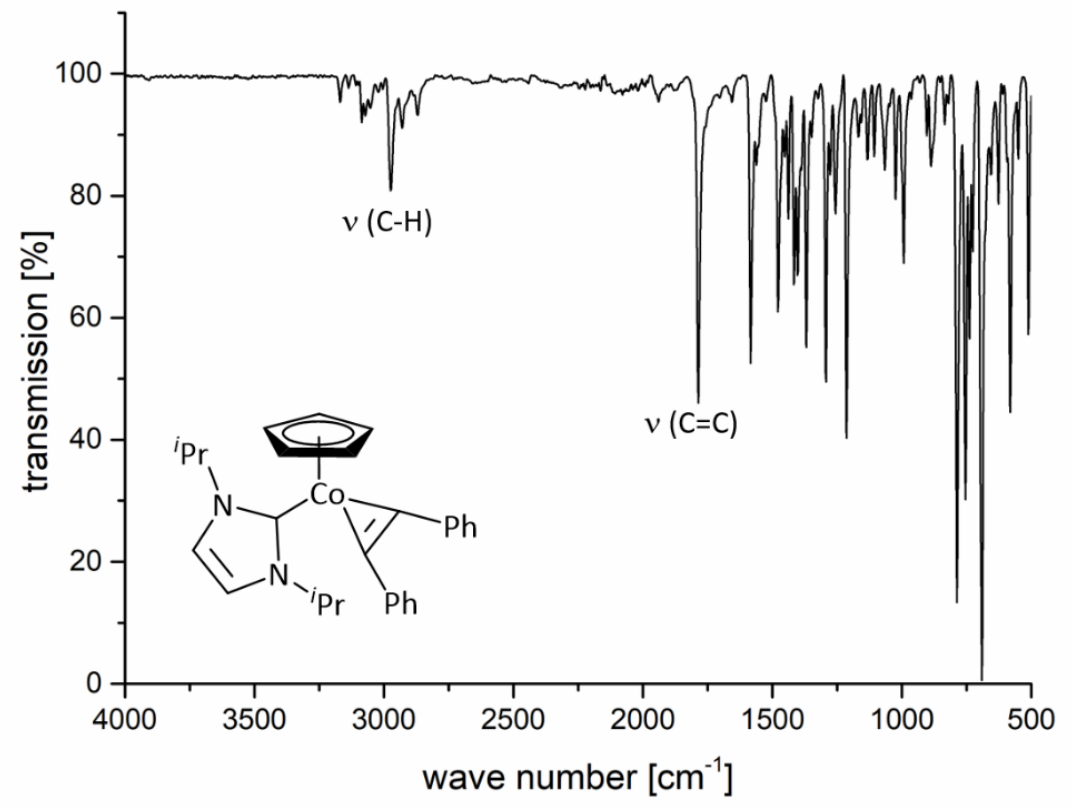

Figure S9: IR spectrum of $\left[\left(\eta^{5}-\mathrm{C}_{5} \mathrm{H}_{5}\right) \mathrm{Co}\left({ }^{i} \mathrm{Pr}_{2} \mathrm{Im}\right)\left(\eta^{2}-\mathrm{C}_{2} \mathrm{Ph}_{2}\right)\right](3)$.

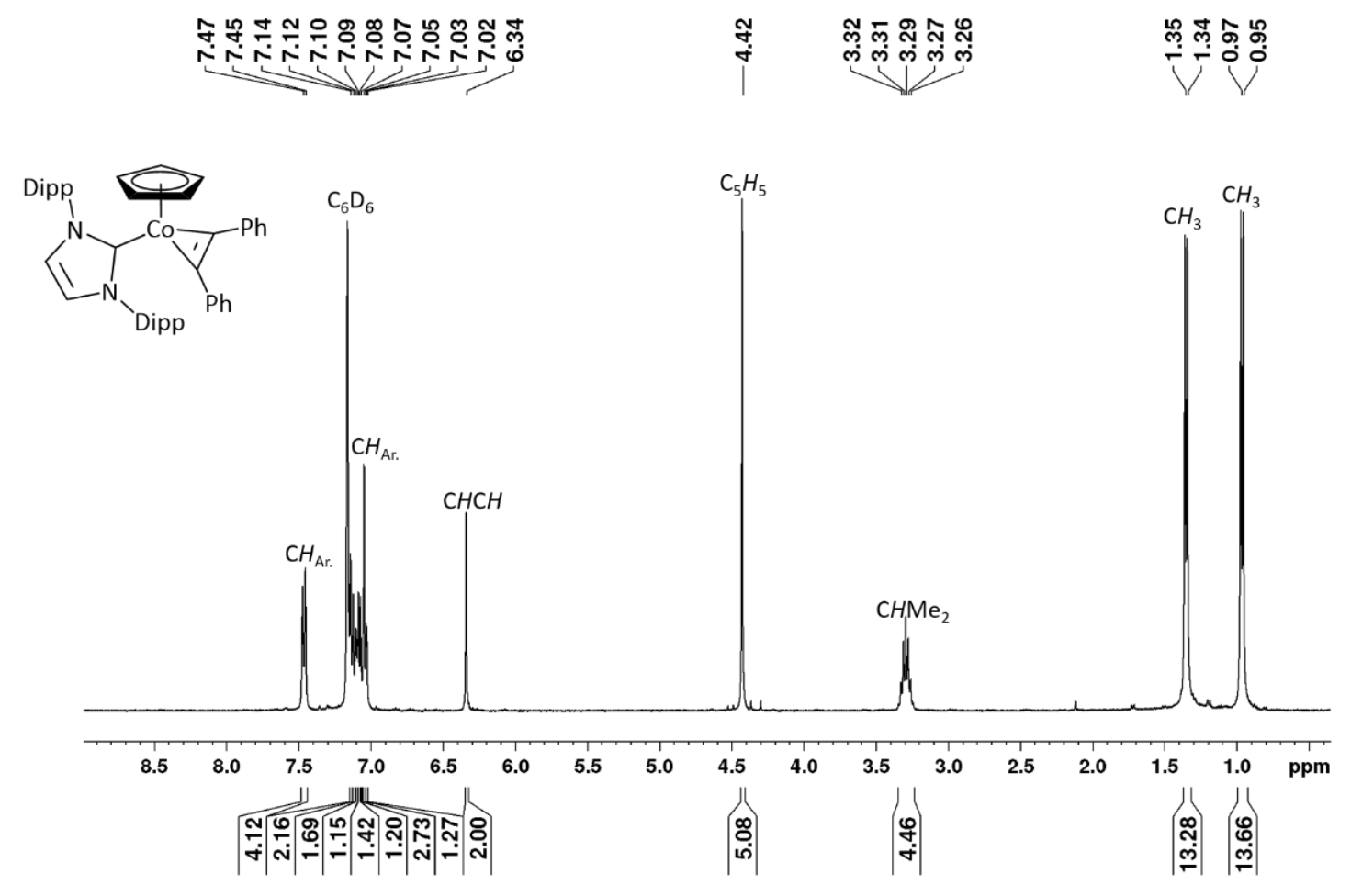

Figure S10: ${ }^{1} \mathrm{H}$ NMR spectrum of $\left[\left(\eta^{5}-\mathrm{C}_{5} \mathrm{H}_{5}\right) \mathrm{Co}\left(\mathrm{Dipp}_{2} \mathrm{Im}\right)\left(\eta^{2}-\mathrm{C}_{2} \mathrm{Ph}_{2}\right)\right](4)$ in $\mathrm{C}_{6} \mathrm{D}_{6}$. 


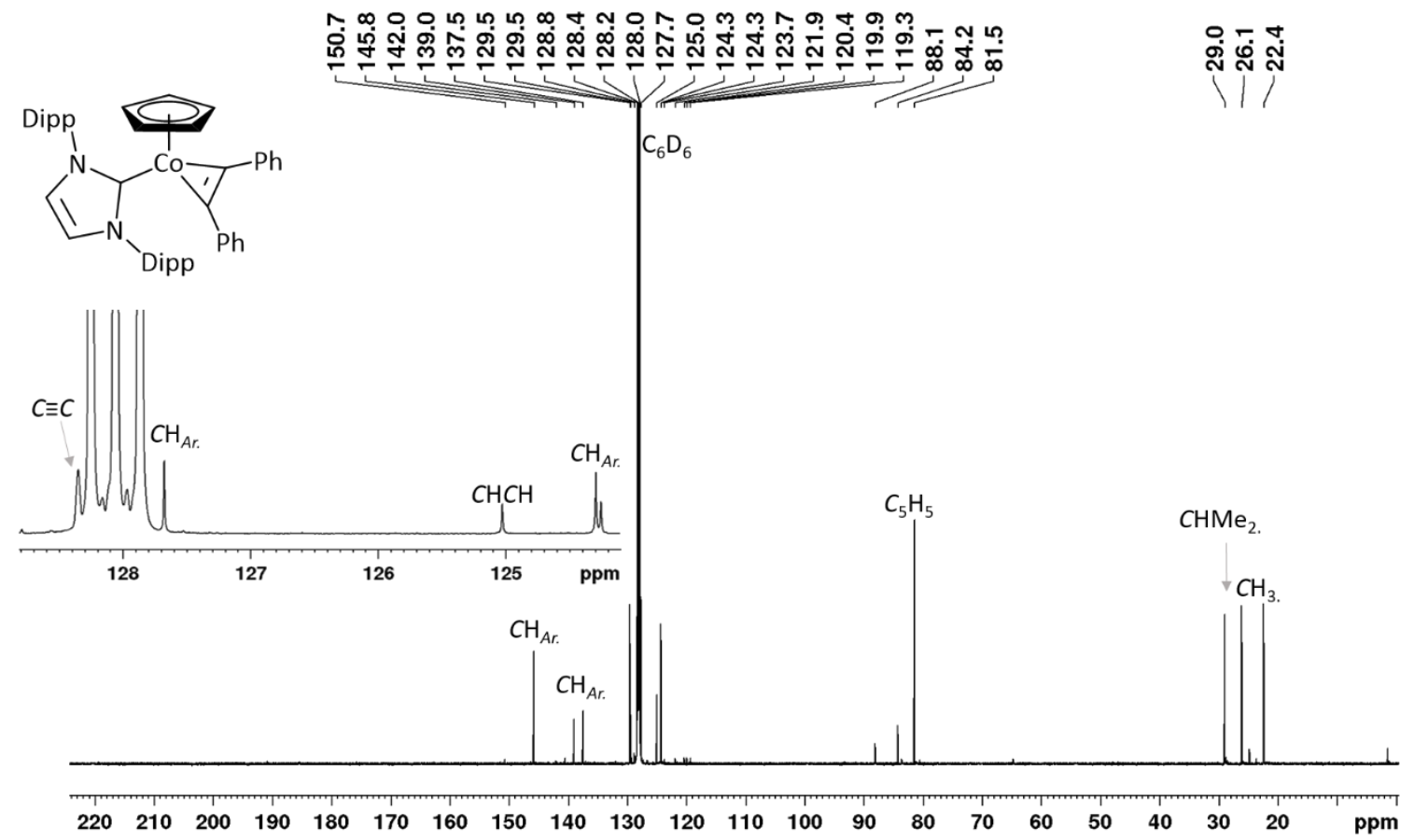

Figure S11: ${ }^{13} \mathrm{C}\left\{{ }^{1} \mathrm{H}\right\}$ NMR spectrum of $\left[\left(\eta^{5}-\mathrm{C}_{5} \mathrm{H}_{5}\right) \mathrm{Co}\left(\mathrm{Dipp}_{2} \mathrm{Im}\right)\left(\eta^{2}-\mathrm{C}_{2} \mathrm{Ph}_{2}\right)\right](4)$ in $\mathrm{C}_{6} \mathrm{D}_{6}$. The resonance of the carbene carbon atom have been identified in a ${ }^{13} \mathrm{C}\left\{{ }^{1} \mathrm{H}\right\} \mathrm{HMBC}$ experiment at $196.6 \mathrm{ppm}$.

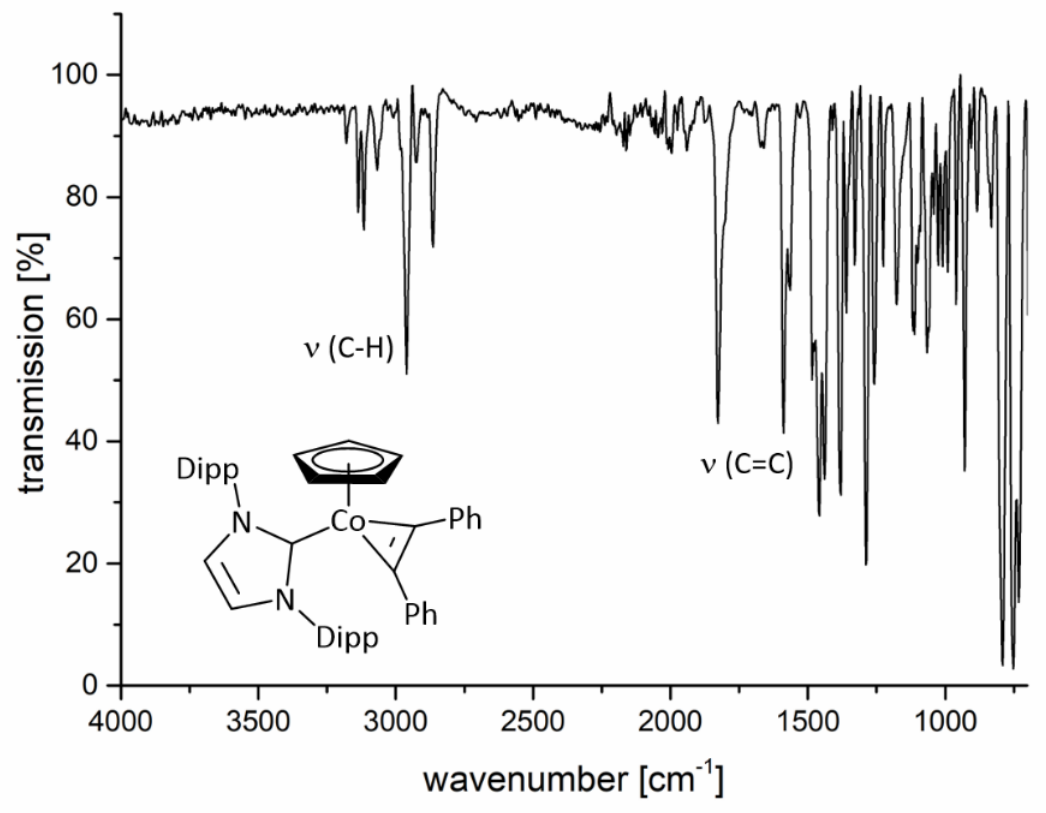

Figure S12: IR spectrum of $\left[\left(\eta^{5}-\mathrm{C}_{5} \mathrm{H}_{5}\right) \mathrm{Co}\left(\mathrm{Dipp}_{2} \mathrm{Im}\right)\left(\eta^{2}-\mathrm{C}_{2} \mathrm{Ph}_{2}\right)\right](4)$. 


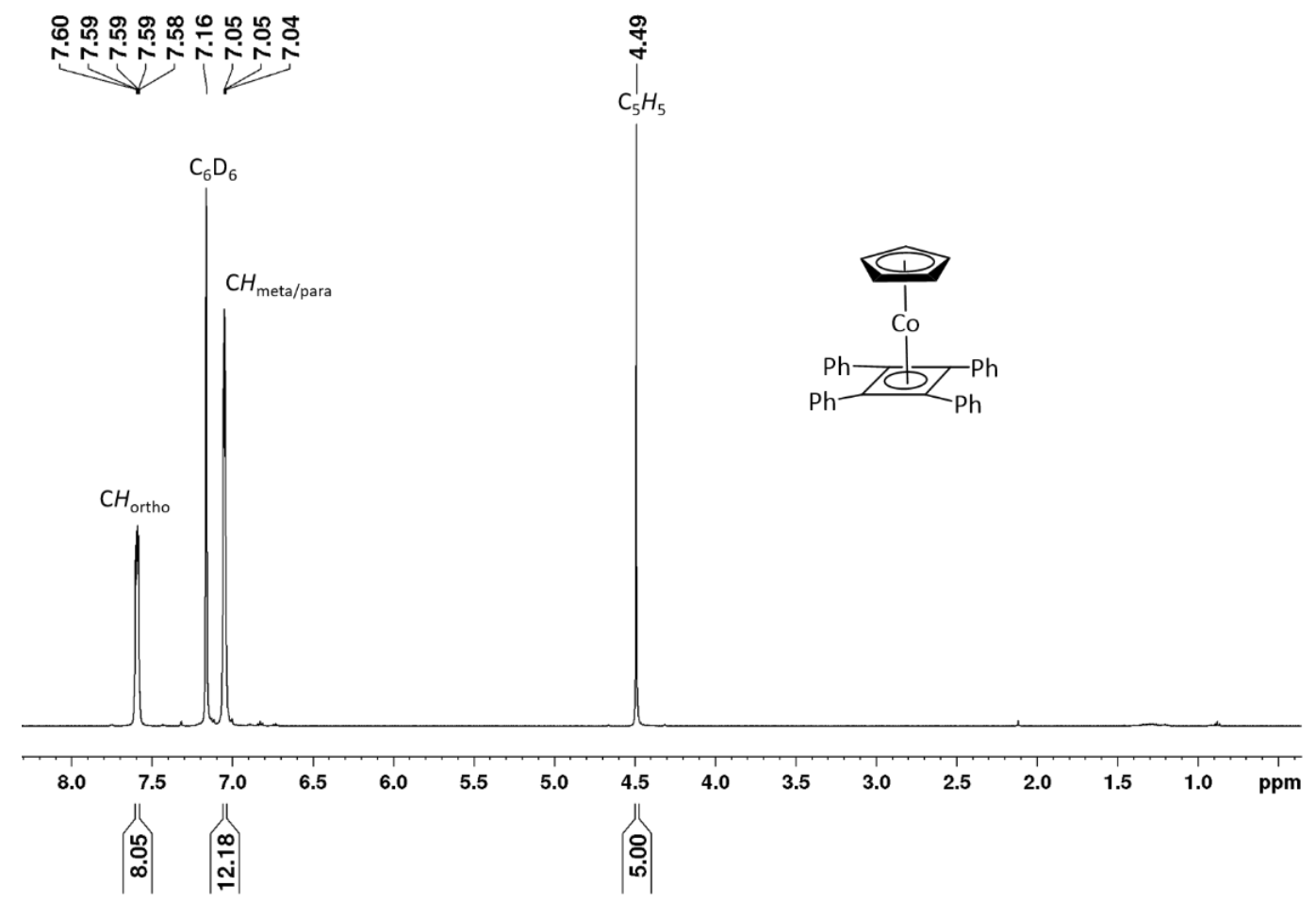

Figure S13: ${ }^{1} \mathrm{H}$ NMR spectrum of $\left[\left(\eta^{5}-\mathrm{C}_{5} \mathrm{H}_{5}\right) \mathrm{Co}\left(\eta^{4}-\mathrm{C}_{4} \mathrm{Ph}_{4}\right)\right](5)$ in $\mathrm{C}_{6} \mathrm{D}_{6}$.

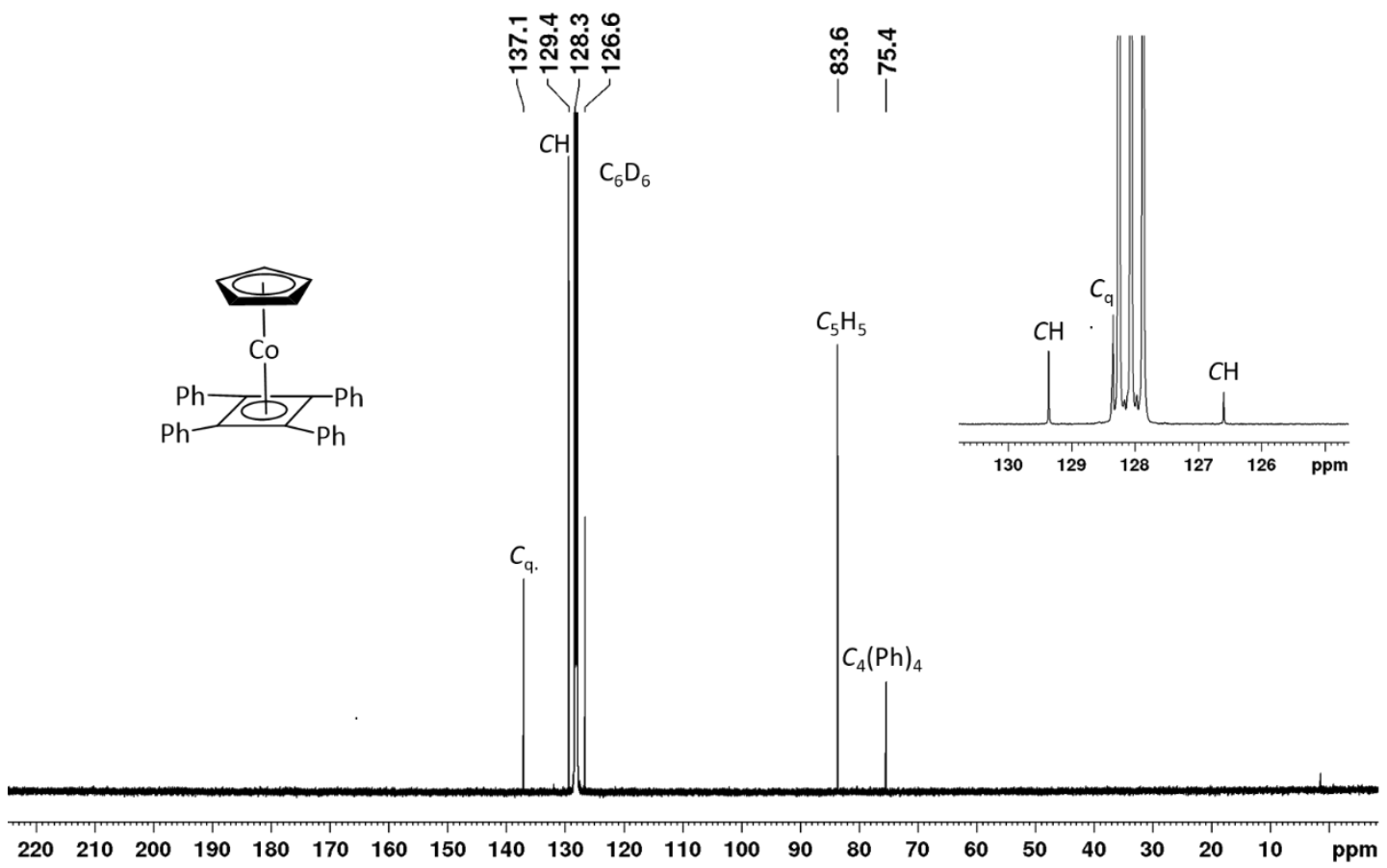

Figure S14: $\left.{ }^{13} C_{\{}{ }^{1} \mathrm{H}\right\}$ NMR spectrum of $\left[\left(\eta^{5}-\mathrm{C}_{5} \mathrm{H}_{5}\right) \mathrm{Co}\left(\eta^{4}-\mathrm{C}_{4} \mathrm{Ph}_{4}\right)\right](5)$ in $\mathrm{C}_{6} \mathrm{D}_{6}$. 


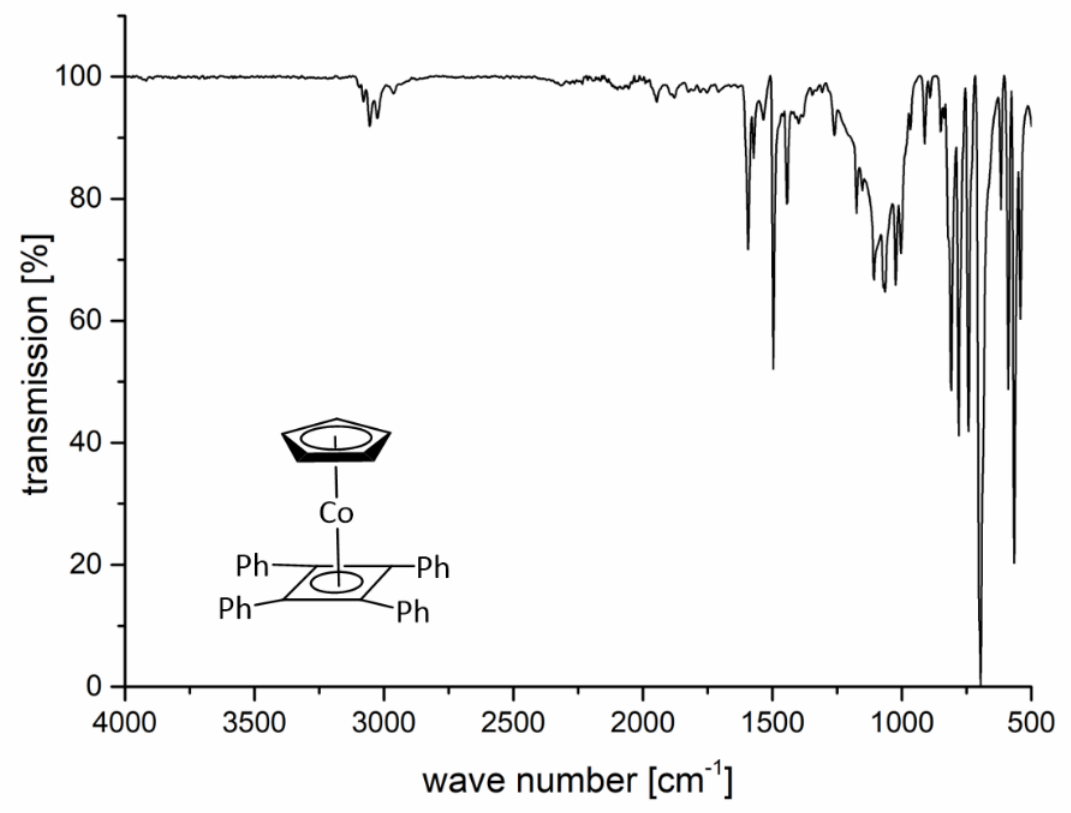

Figure S15: IR spectrum of $\left[\left(\eta^{5}-\mathrm{C}_{5} \mathrm{H}_{5}\right) \mathrm{Co}\left(\eta^{4}-\mathrm{C}_{4} \mathrm{Ph}_{4}\right)\right](5)$.

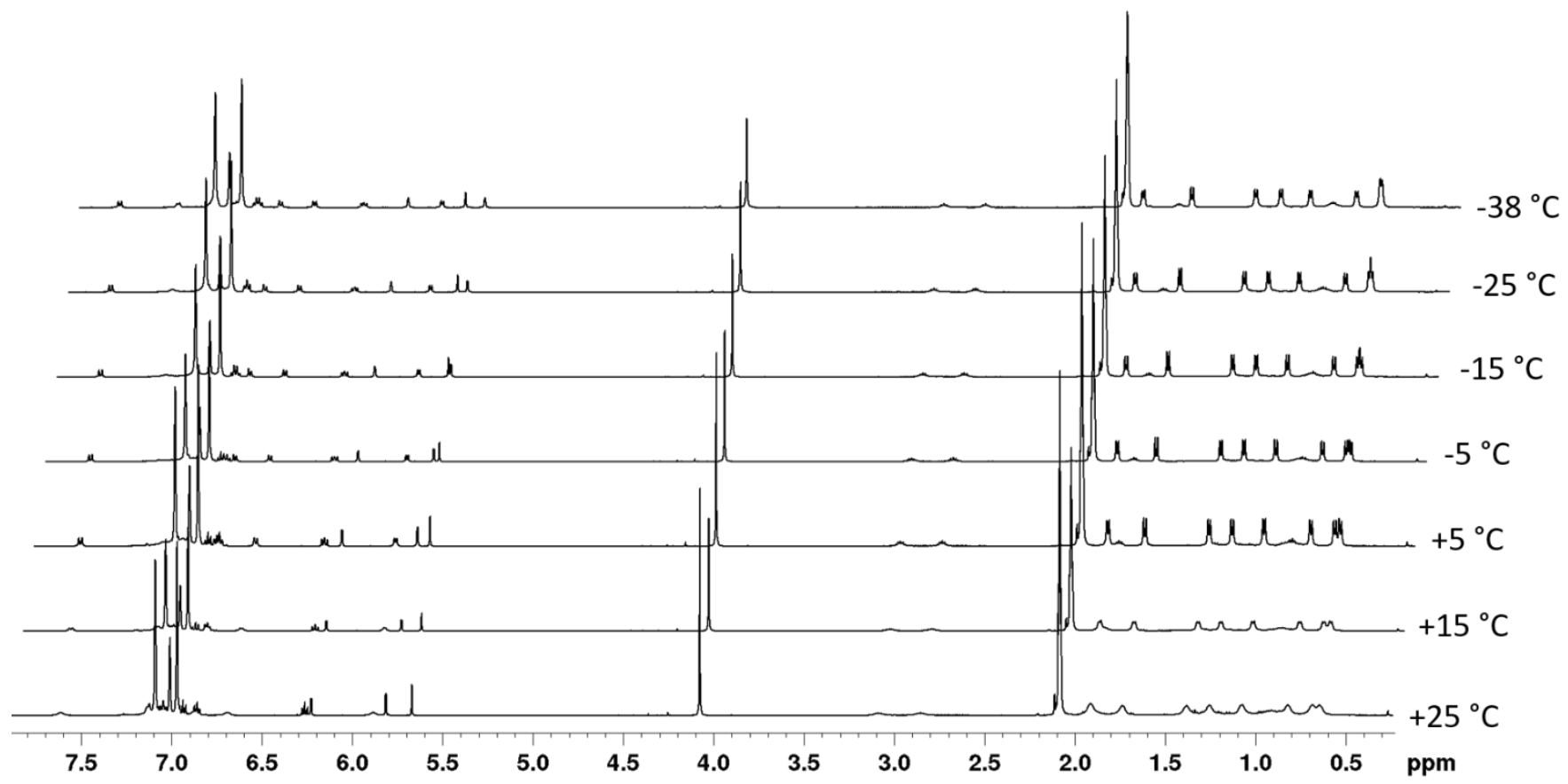

Figure S16: ${ }^{1} \mathrm{H}$ NMR s pectra of $\left[\left(\eta^{5}-\mathrm{C}_{5} \mathrm{H}_{5}\right) \mathrm{Co}\left(-\mathrm{C}\{\mathrm{Ph}\}=\mathrm{C}\{\mathrm{H}\}\left\{\mathrm{Dipp} \mathrm{D}_{2} \mathrm{Im}\right\}\right)\right](6)$ at different temperatures in $d^{8}$ toluene. The resonances of the methyl and methine protons of the Dipp iso-propyl groups are broadened at room temperature, presumably due to on/off coordination of one of the aryl ring $\pi$-system at the Co a tom (see drawing below), associated with dyna mics of the NHC unit of the complex. At temperatures below $+10^{\circ} \mathrm{C}$ the resonances became sharp. 


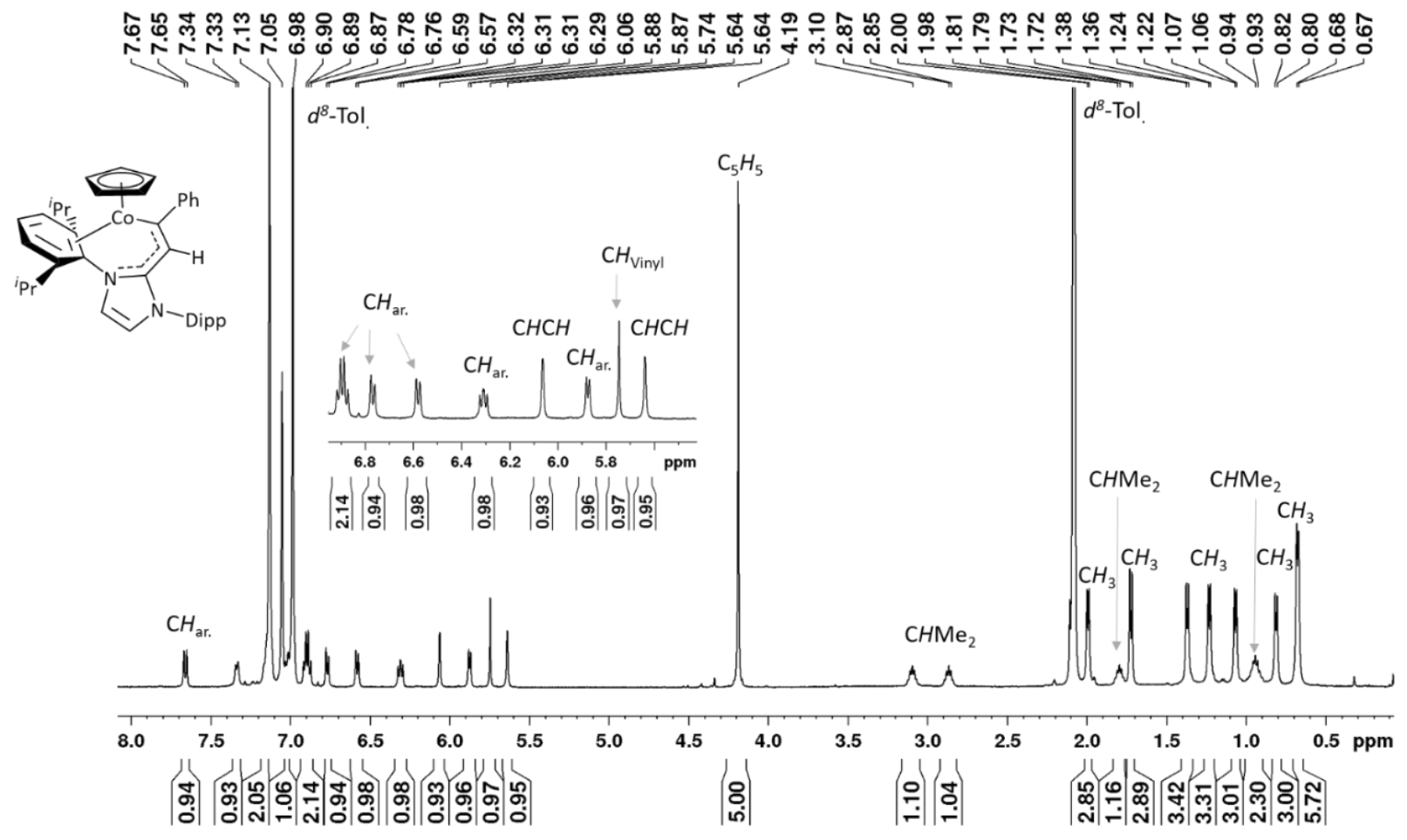

Figure S17: ${ }^{1} \mathrm{H}$ NMR spectrum of $\left[\left(\eta^{5}-\mathrm{C}_{5} \mathrm{H}_{5}\right) \mathrm{Co}(-\mathrm{C}\{\mathrm{Ph}\}=C\{\mathrm{H}\}\{\right.$ Dipp $\left.2 \mathrm{Im}\})\right](6)$ at $-38^{\circ} \mathrm{C}$ in $\mathrm{d}^{8}$ toluene.

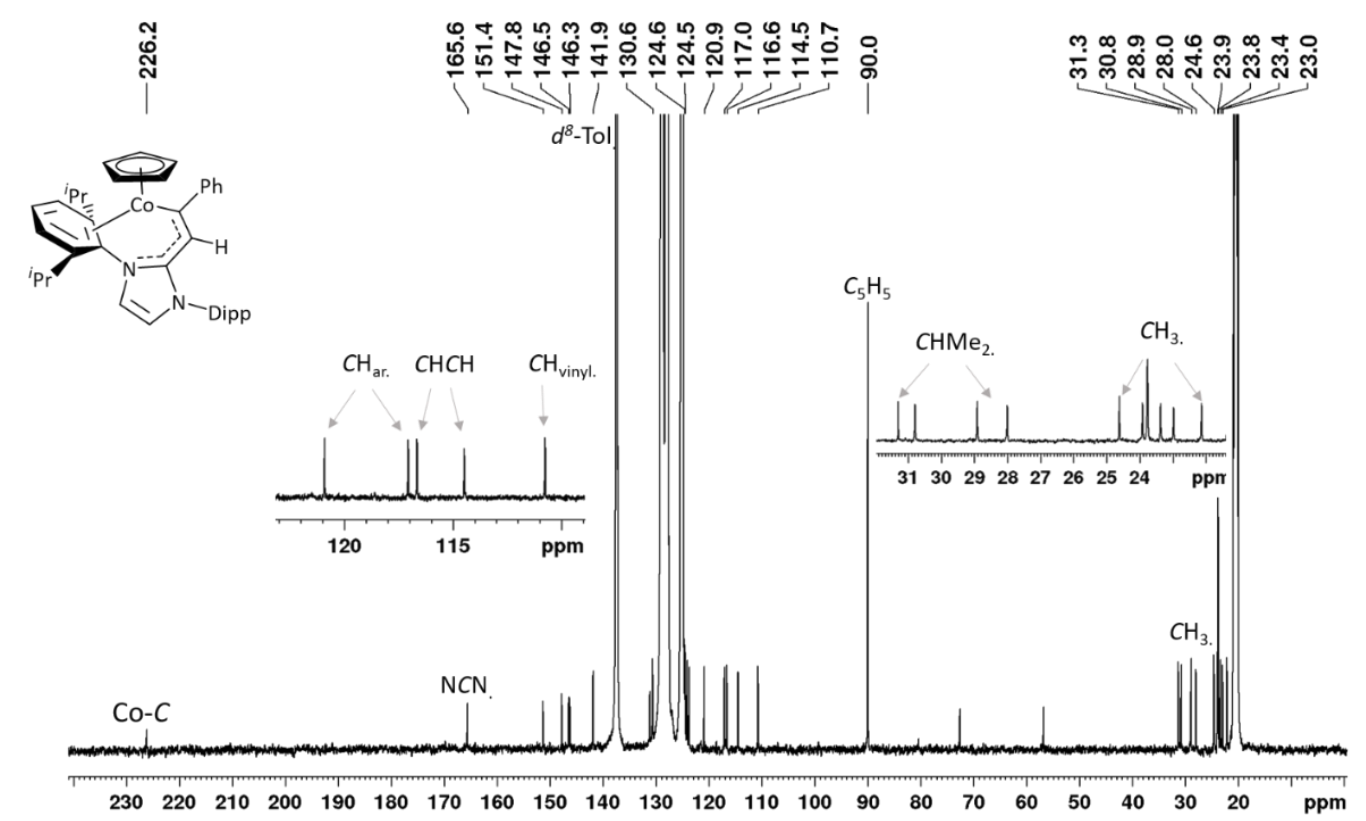

Figure S18: ${ }^{13} \mathrm{C}\left\{{ }^{1} \mathrm{H}\right\}$ NMR spectrum of $\left[\left(\eta^{5}-\mathrm{C}_{5} \mathrm{H}_{5}\right) \mathrm{Co}\left(-\mathrm{C}\{\mathrm{Ph}\}=\mathrm{C}\{\mathrm{H}\}\left\{\mathrm{Dipp} \mathrm{Dip}_{2} \mathrm{~m}\right\}\right)\right](6)$ at $-38{ }^{\circ} \mathrm{C}$ in $d^{8}$ toluene. 


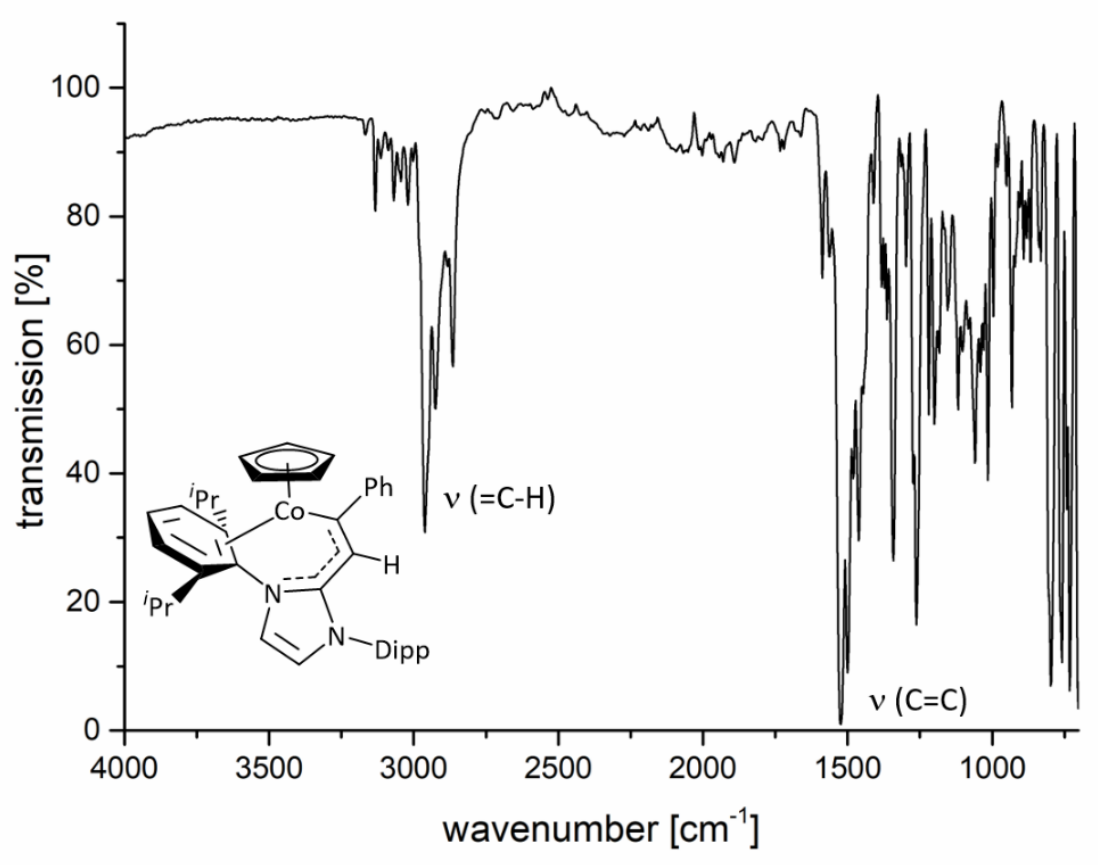

Figure S19: IR spectrum of $\left[\left(\eta^{5}-\mathrm{C}_{5} \mathrm{H}_{5}\right) \mathrm{Co}\left(-\mathrm{C}\{\mathrm{Ph}\}=\mathrm{C}\{\mathrm{H}\}\left\{\right.\right.\right.$ Dipp $\left.\left.\left._{2} \mathrm{Im}\right\}\right)\right](6)$.

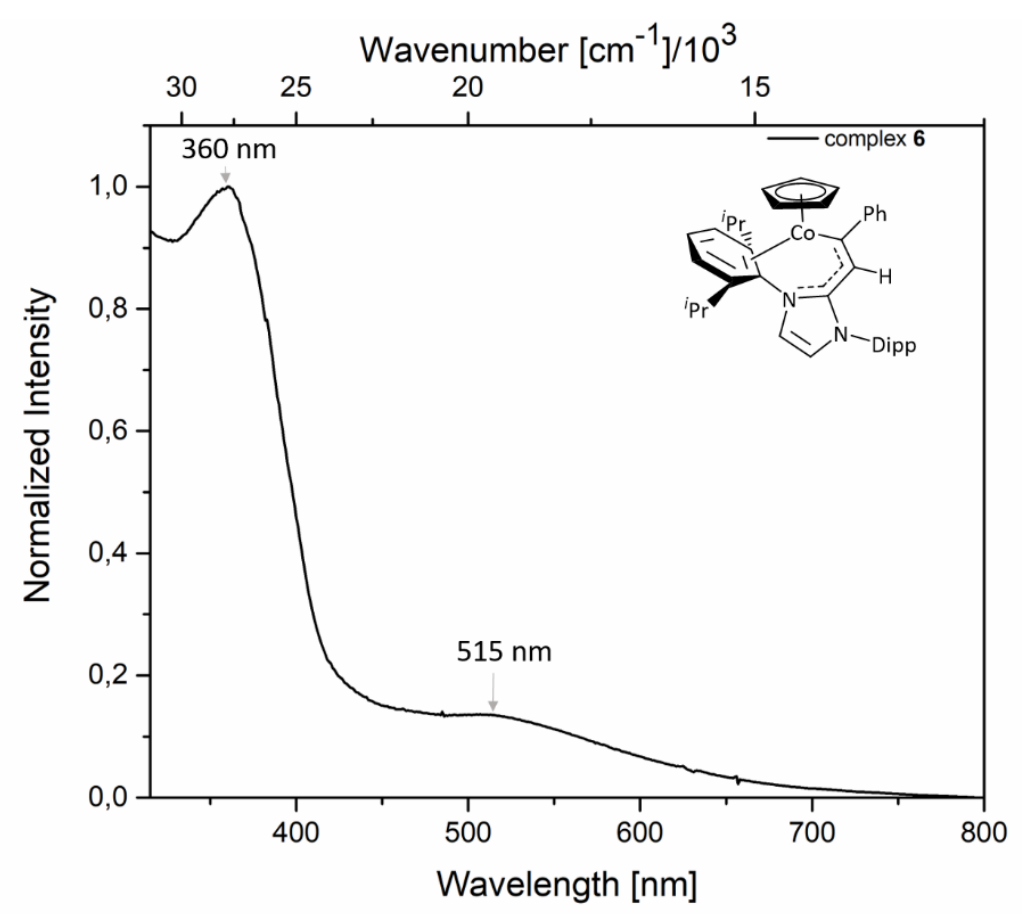

Figure S20: UV-Vis spectrum of $\left[\left(\eta^{5}-C_{5} H_{5}\right) C o(-C\{P h\}=C\{H\}\{\right.$ Dipp $\left.2 I m\})\right](6)$. 


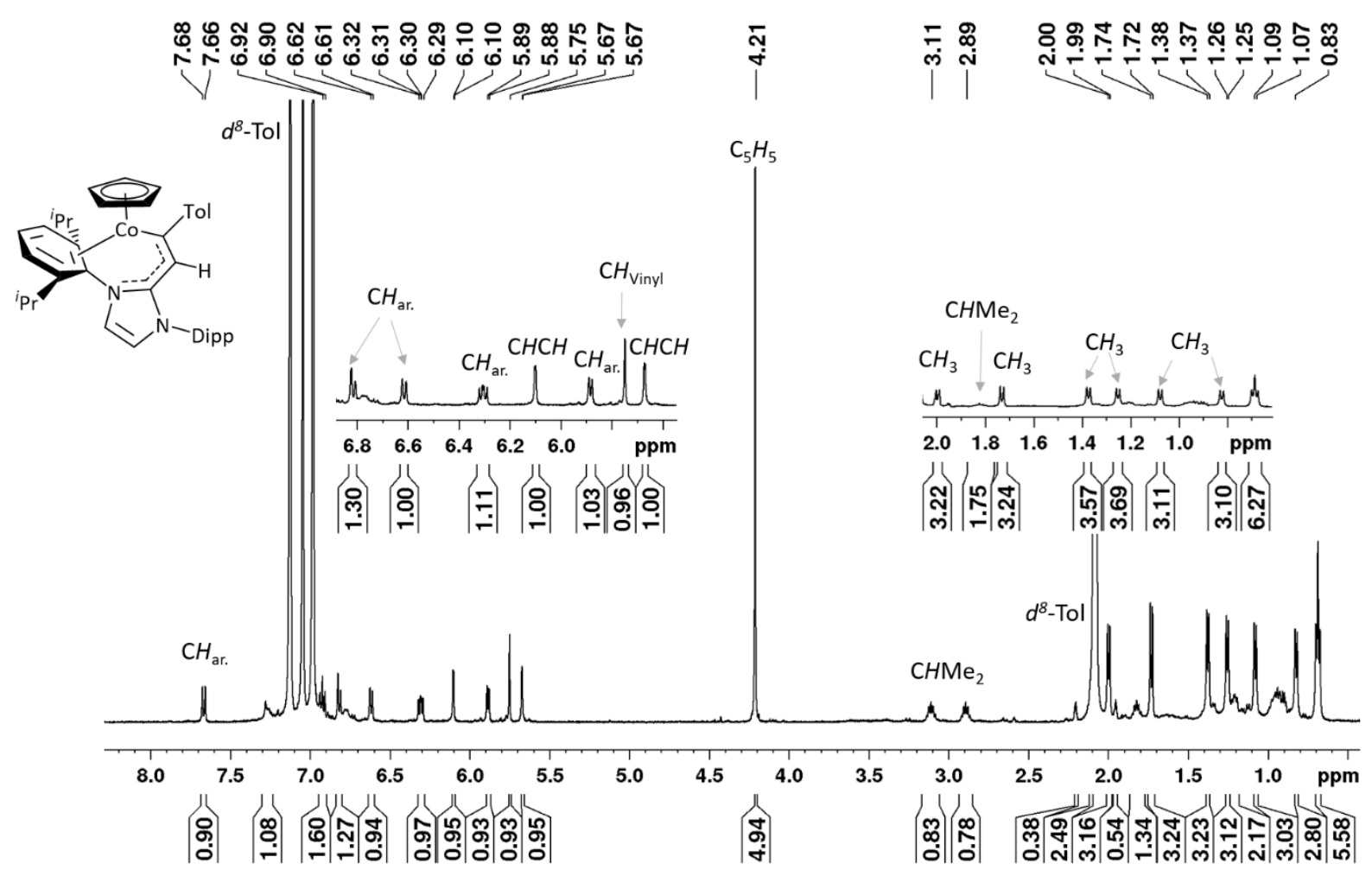

Figure S21: ${ }^{1} \mathrm{H}$ NMR spectrum of $\left[\left(\eta^{5}-\mathrm{C}_{5} \mathrm{H}_{5}\right) \mathrm{Co}(-\mathrm{C}\{\mathrm{Tol}\}=\mathrm{C}\{\mathrm{H}\}\{\right.$ Dipp $\left.2 \mathrm{Im}\})\right](7)$ at $-38^{\circ} \mathrm{C}$ in $d^{8}$ toluene.

กั

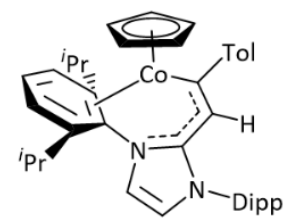

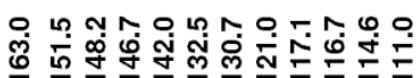

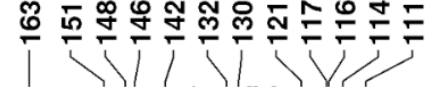

ธั.

$$
d^{8}-\text { Tol. }
$$

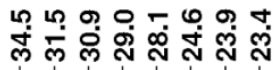

管

$d^{8}$-Tol

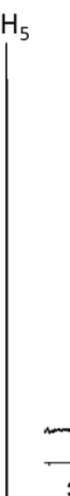

$\mathrm{CHCH}$
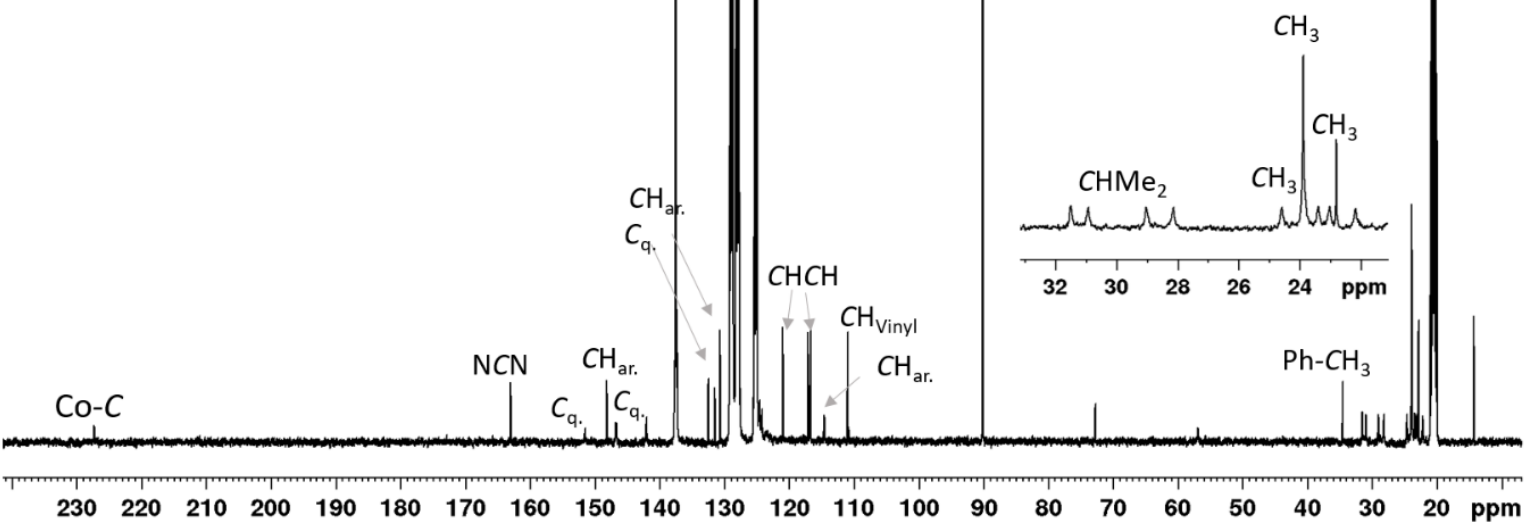

$\mathrm{Ph}-\mathrm{CH}_{3}$

Figure S22: ${ }^{13} \mathrm{C}\left\{{ }^{1} \mathrm{H}\right\}$ NMR spectrum of $\left[\left(\eta^{5}-\mathrm{C}_{5} \mathrm{H}_{5}\right) \mathrm{Co}(-\mathrm{C}\{\mathrm{Tol}\}=\mathrm{C}\{\mathrm{H}\}\{\right.$ Dipp $\left.2 \mathrm{Im}\})\right](7)$ at $+25^{\circ} \mathrm{C}$ in $d^{8}$ toluene. 


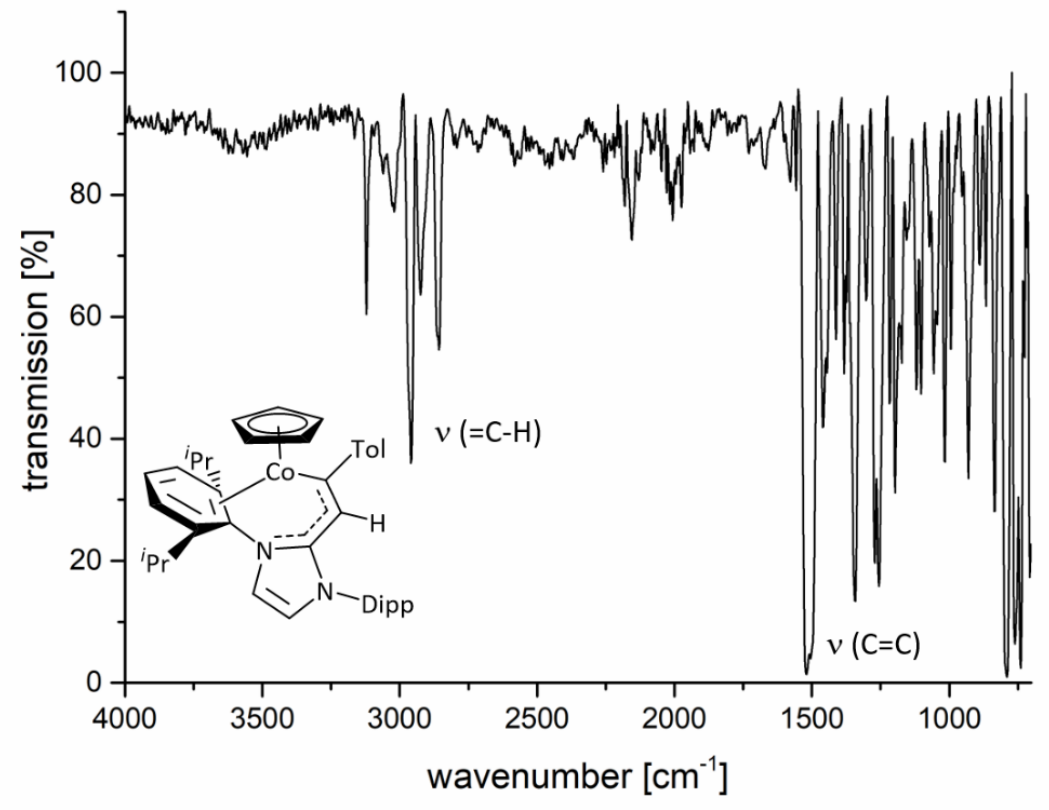

Figure S23: IR spectrum of $\left[\left(\eta^{5}-\mathrm{C}_{5} \mathrm{H}_{5}\right) \mathrm{Co}\left(-\mathrm{C}\{\mathrm{Tol}\}=\mathrm{C}\{\mathrm{H}\}\left\{\right.\right.\right.$ Dipp $\left.\left.\left._{2} \mathrm{Im}\right\}\right)\right](7)$.

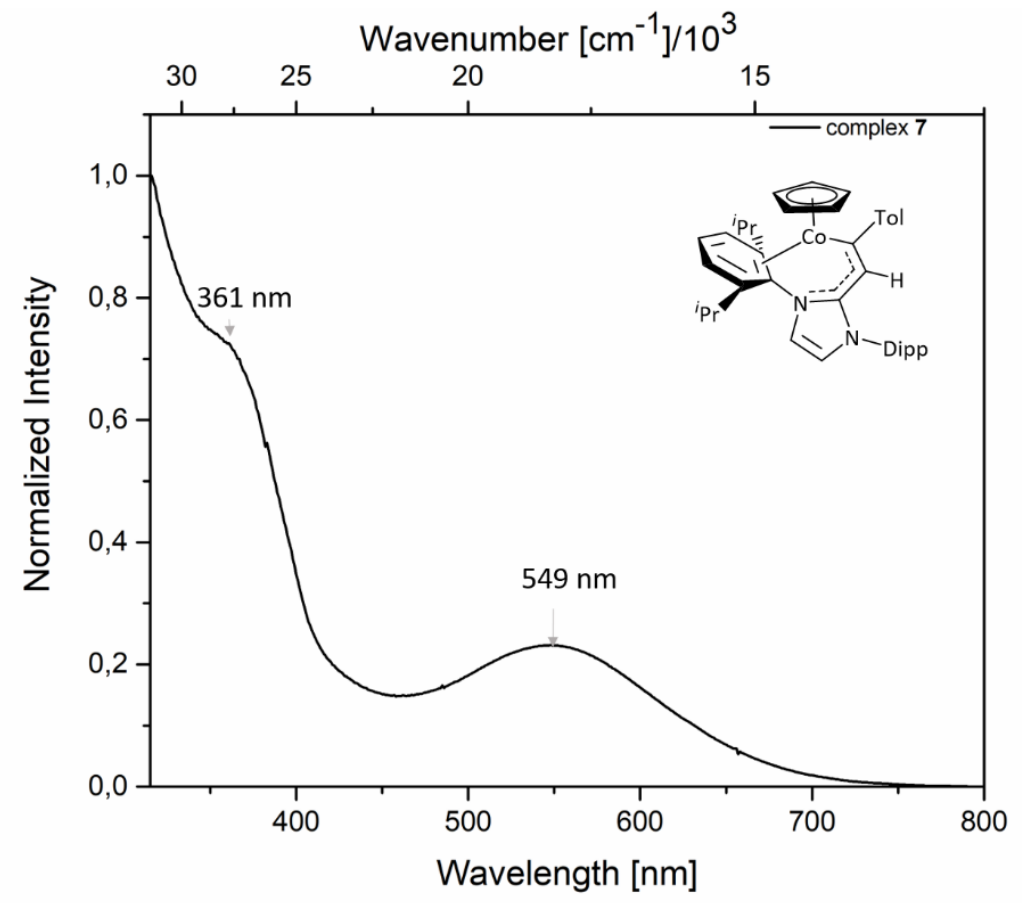

Figure S24: UV-Vis spectrum of $\left[\left(\eta^{5}-C_{5} H_{5}\right) C o\left(-C\{T o l\}=C\{H\}\left\{D i p p_{2} I m\right\}\right)\right](7)$. 


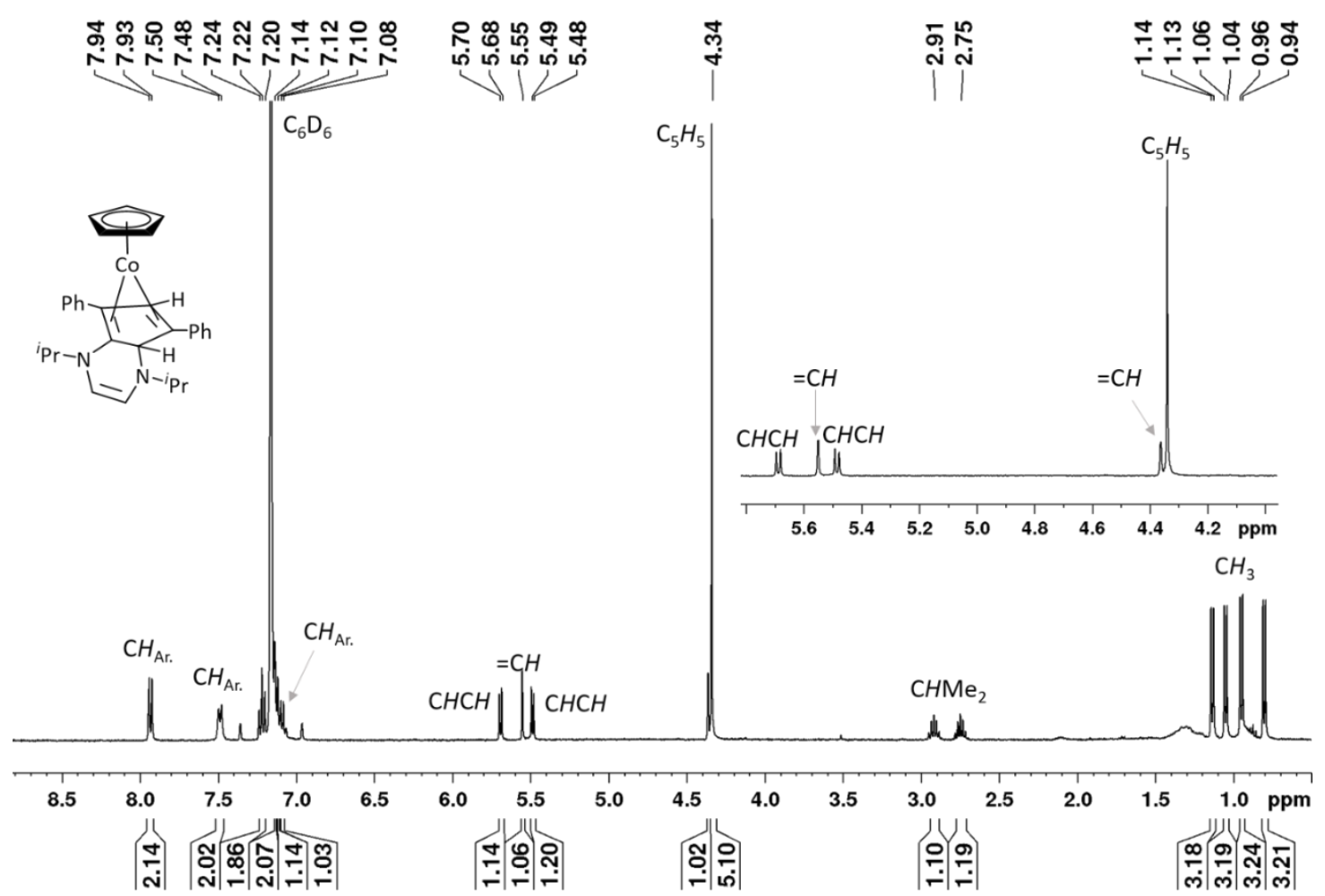

Figure S25: ${ }^{1} \mathrm{H}$ NMR spectrum of $\left[\left(\eta^{5}-\mathrm{C}_{5} \mathrm{H}_{5}\right) \mathrm{Co}\left(\eta^{4}\left\{(\mathrm{RER}-\mathrm{NHC}) \mathrm{C}_{4} \mathrm{H}_{2} \mathrm{Ph}_{2}\right\}\right](8)\right.$ in $\mathrm{C}_{6} \mathrm{D}_{6}$.

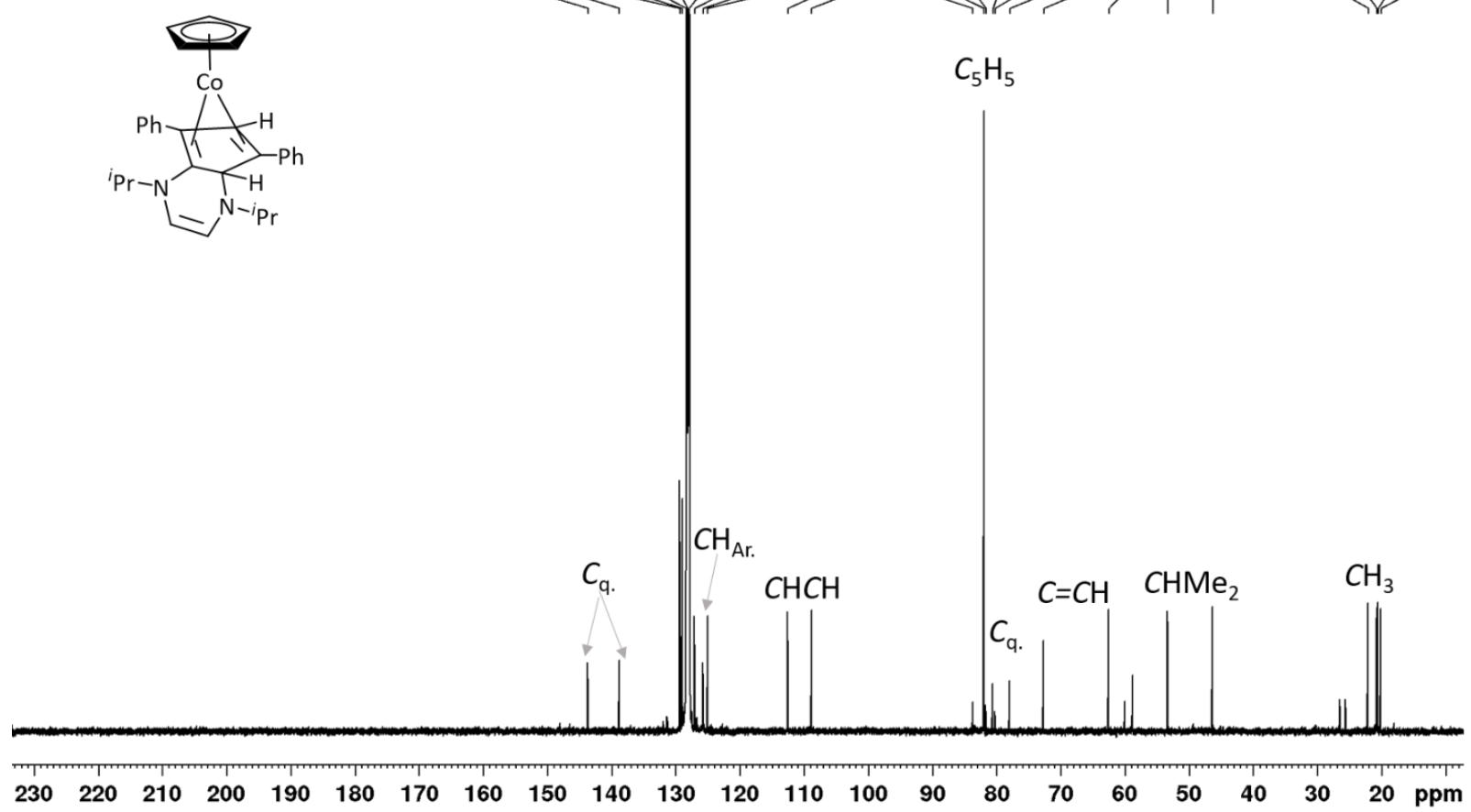

Figure S26: ${ }^{13} \mathrm{C}\left\{{ }^{1} \mathrm{H}\right\}$ NMR spectrum of $\left[\left(\eta^{5}-\mathrm{C}_{5} \mathrm{H}_{5}\right) \mathrm{Co}\left(\eta^{4}\left\{(\mathrm{RER}-\mathrm{NHC}) \mathrm{C}_{4} \mathrm{H}_{2} \mathrm{Ph}_{2}\right\}\right]\right.$ (8) in $\mathrm{C}_{6} \mathrm{D}_{6}$. 


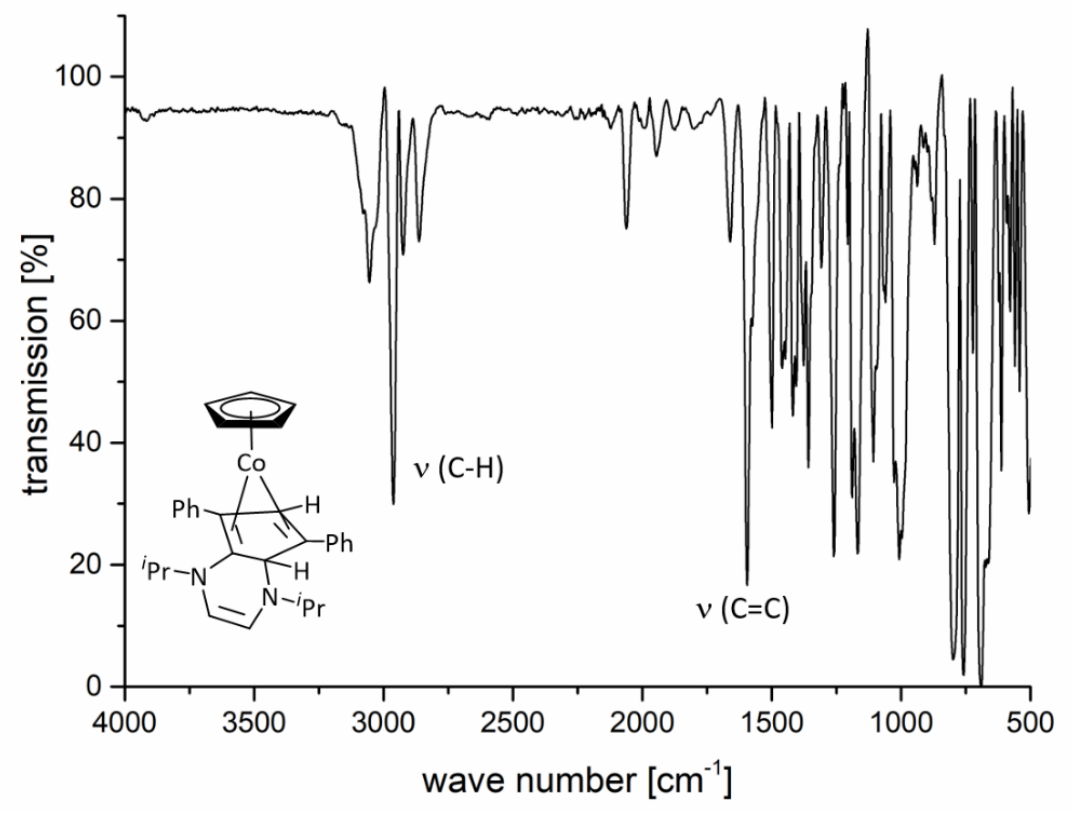

Figure 27: IR spectrum of $\left[\left(\eta^{5}-\mathrm{C}_{5} \mathrm{H}_{5}\right) \mathrm{Co}\left(\eta^{4}\left\{(\mathrm{RER}-\mathrm{NHC}) \mathrm{C}_{4} \mathrm{H}_{2} \mathrm{Ph}_{2}\right\}\right]\right.$ (8).

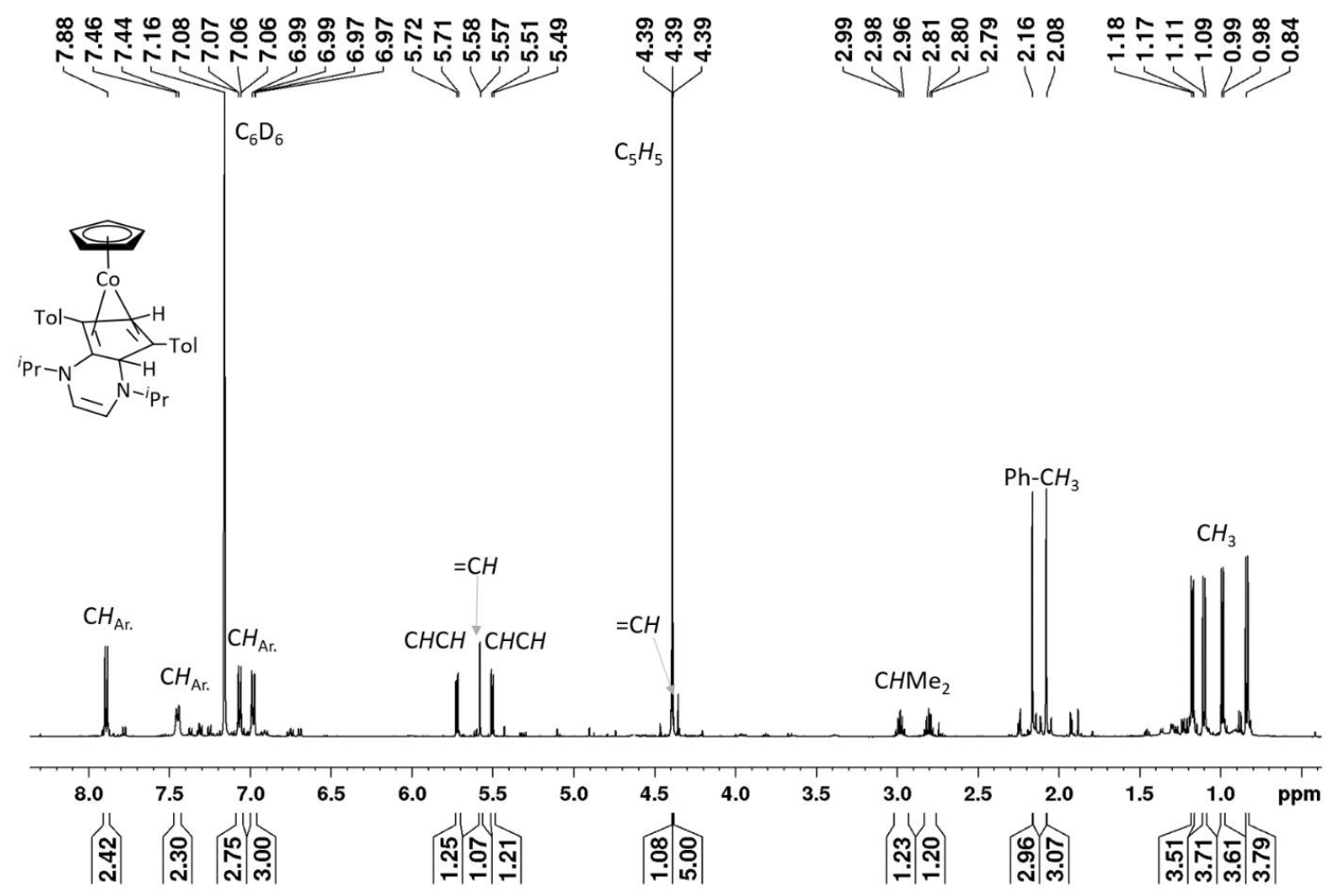

Figure S28: ${ }^{1} \mathrm{H}$ NMR spectrum of $\left[\left(\eta^{5}-\mathrm{C}_{5} \mathrm{H}_{5}\right) \mathrm{Co}\left(\eta^{4}\left\{(\mathrm{RER}-\mathrm{NHC}) \mathrm{C}_{4} \mathrm{H}_{2} \mathrm{Tol}_{2}\right\}\right]\right.$ (9) in $\mathrm{C}_{6} \mathrm{D}_{6}$. 


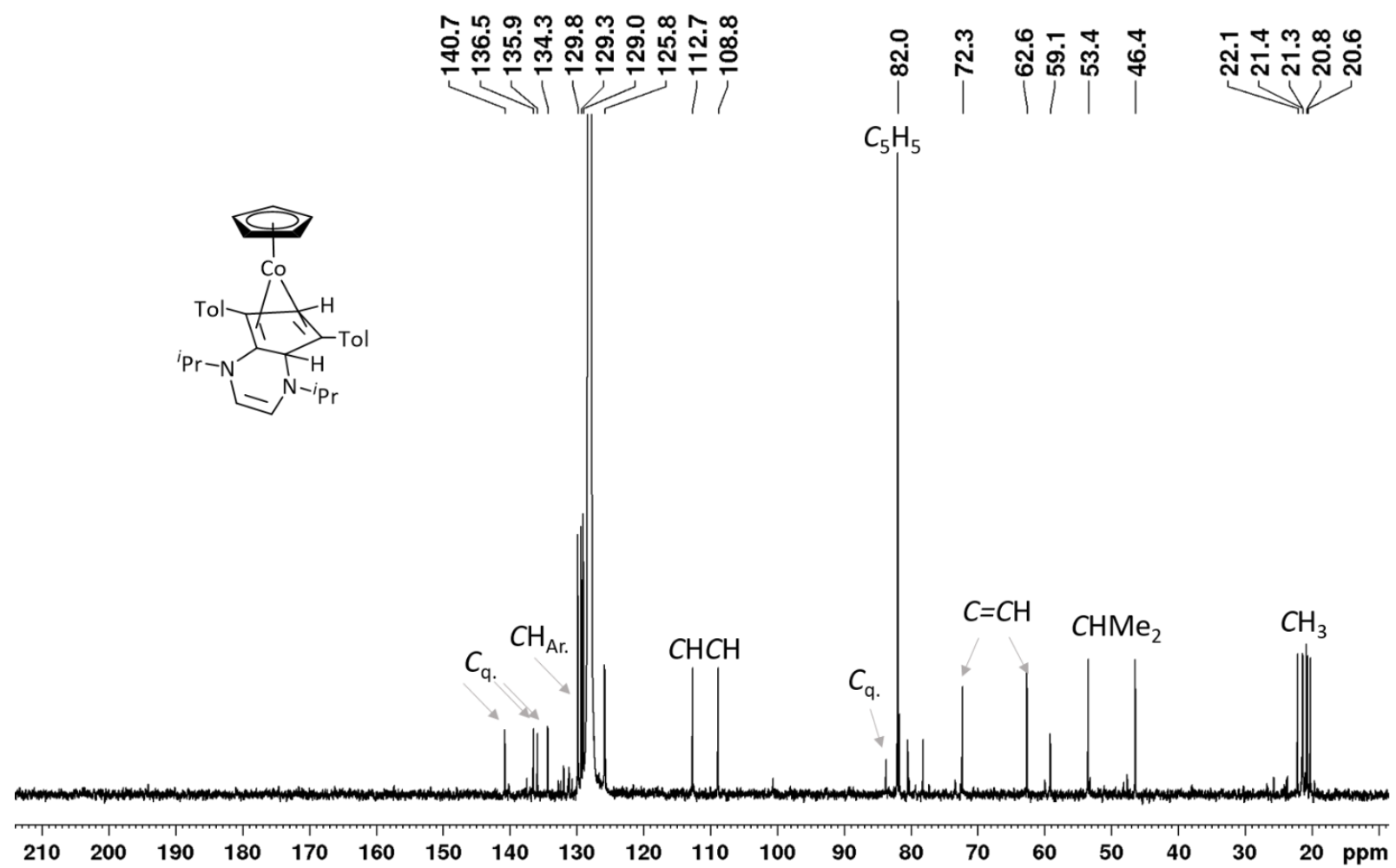

Figure S29: ${ }^{13} \mathrm{C}\left\{{ }^{1} \mathrm{H}\right\}$ NMR spectrum of $\left[\left(\eta^{5}-\mathrm{C}_{5} \mathrm{H}_{5}\right) \mathrm{Co}\left(\eta^{4}\left\{(\mathrm{RER}-\mathrm{NHC}) \mathrm{C}_{4} \mathrm{H}_{2} \mathrm{Tol}_{2}\right\}\right]\right.$ (9) in $\mathrm{C}_{6} \mathrm{D}_{6}$.

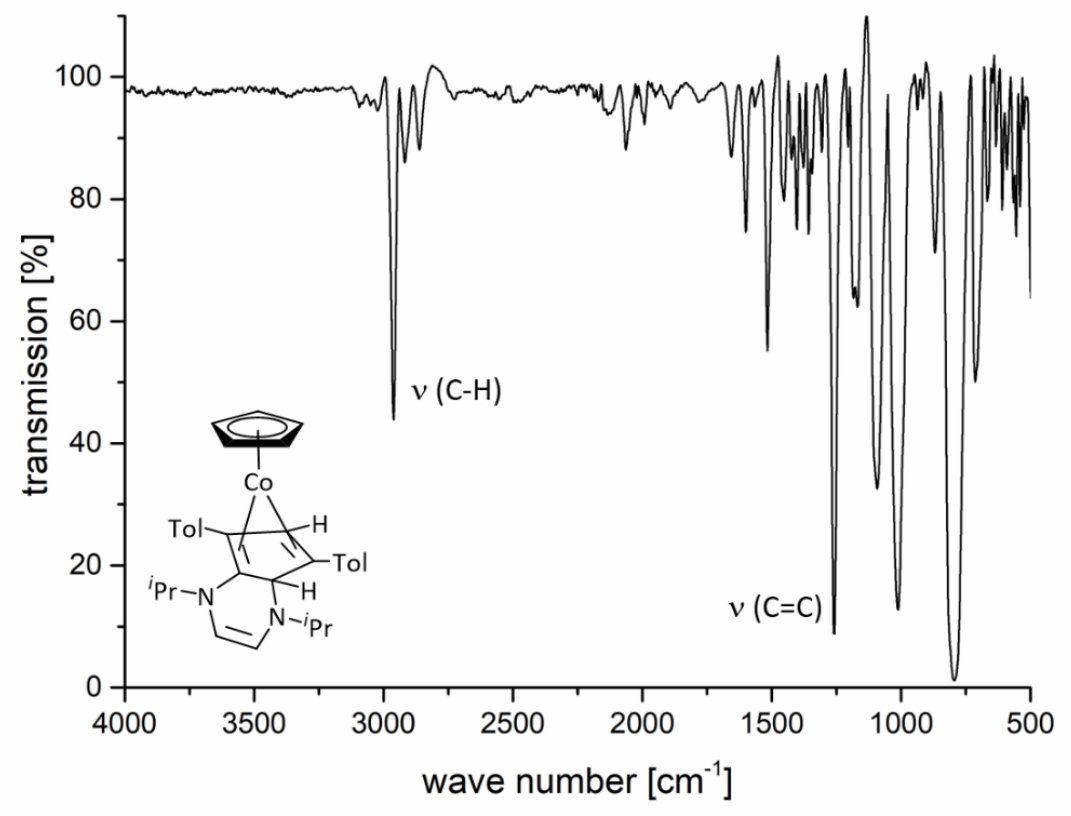

Figure S30: IR spectrum of $\left[\left(\eta^{5}-\mathrm{C}_{5} \mathrm{H}_{5}\right) \mathrm{Co}\left(\eta^{4}\left\{(\mathrm{RER}-\mathrm{NHC}) \mathrm{C}_{4} \mathrm{H}_{2} \mathrm{Tol}_{2}\right\}\right]\right.$ (9). 


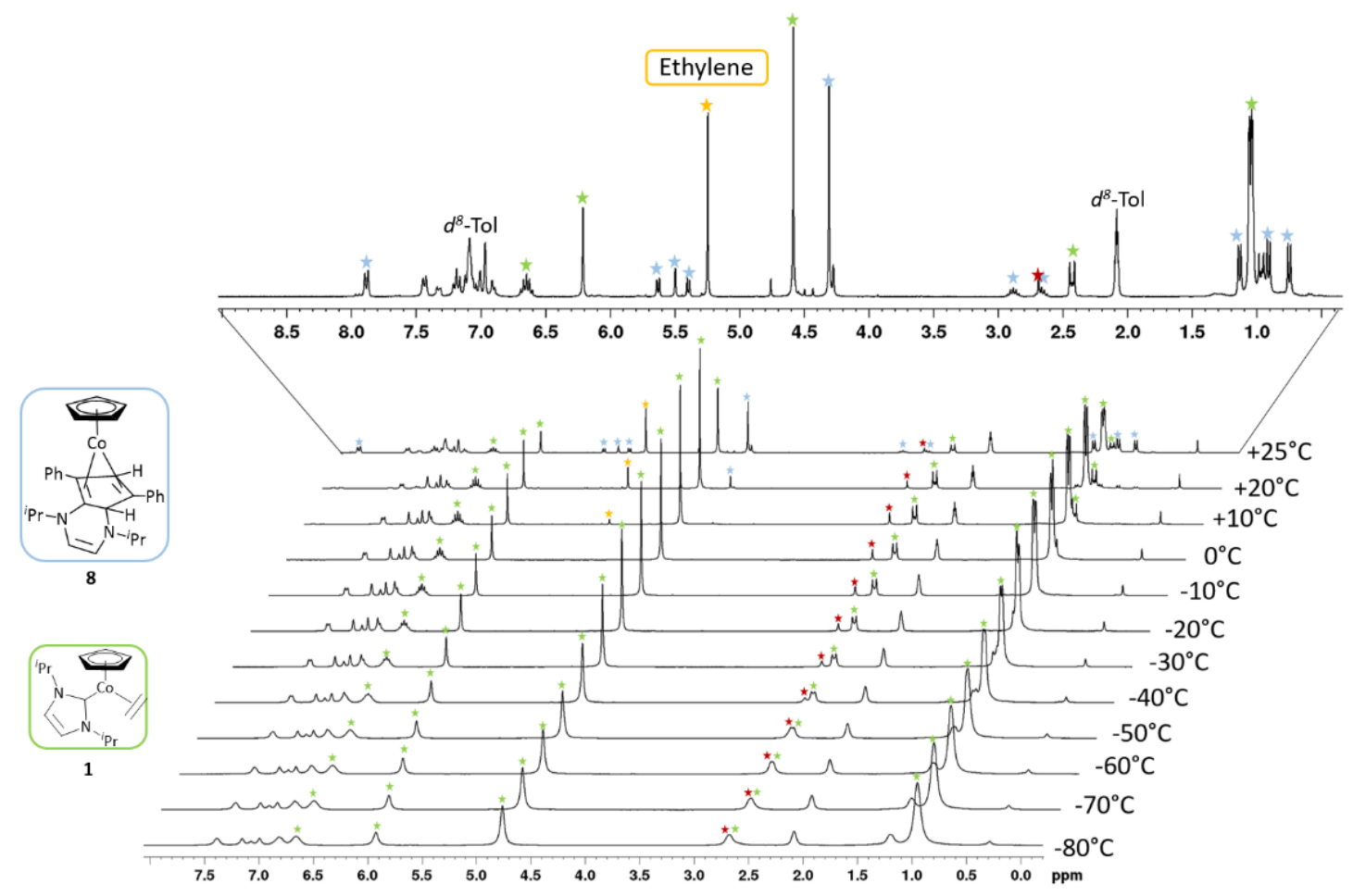

Figure S31: ${ }^{1} \mathrm{H}$ NMR spectra of the reaction of $\left[\left(\eta^{5}-\mathrm{C}_{5} \mathrm{H}_{5}\right) \mathrm{Co}\left({ }^{i} \mathrm{Pr}_{2} \mathrm{Im}\right)\left(\eta^{2}-\mathrm{C}_{2} \mathrm{H}_{4}\right)\right] 1$ (green) with one equivalent phenylacetyl ene (red) in $d^{8}$-toluene at different temperatures starting at $-80^{\circ} \mathrm{C}$. This reaction lea ds directly $\left[\left(\eta^{5}-\mathrm{C}_{5} \mathrm{H}_{5}\right) \mathrm{Co}\left(\eta^{4}\left\{(\mathrm{RER}-\mathrm{NHC}) \mathrm{C}_{4} \mathrm{H}_{2} \mathrm{Ph} \mathrm{R}_{2}\right\}\right](8)\right.$ (blue) (and 1) at $20^{\circ} \mathrm{C}$. After the reaction has been completed, the NMR s pectrum at top reveals a re action mixture of 1 a nd $8 \mathrm{in}$ a ratio round 1:1, as well as free ethylene (yellow). No resonances for any intermediate was detected. 


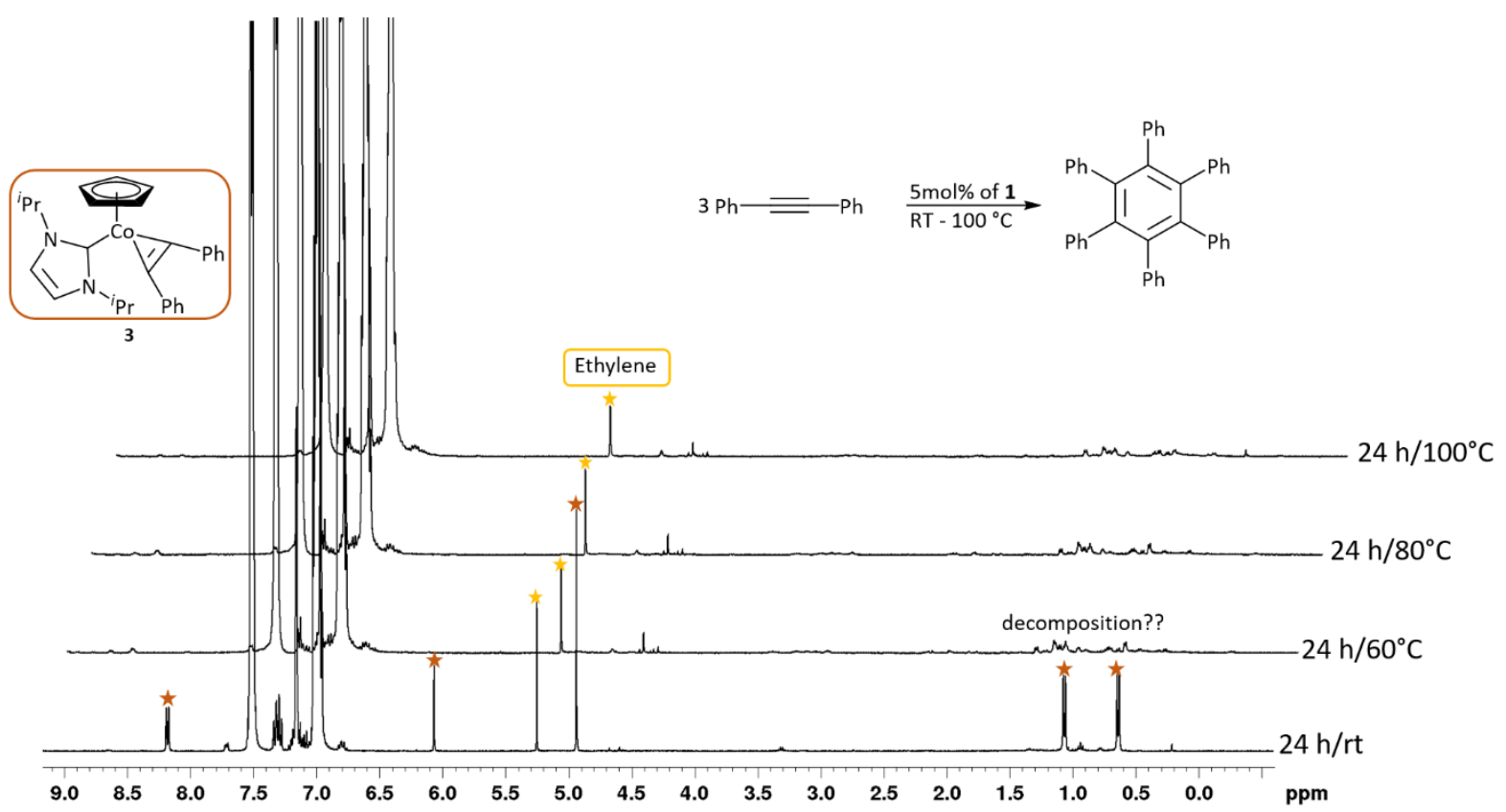

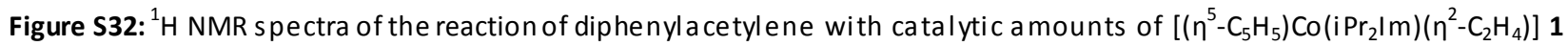
$(5 \mathrm{~mol} \%)$ in $\mathrm{C}_{6} \mathrm{D}_{6}$ at different te mperatures. The NMR spectrum at room temperature reveals the resonances found for complex 3 (brown) and a singlet of free ethylene (yellow), eliminated from starting compound $\mathbf{1}$. At higher temperatures complex $\mathbf{3}$ decomposes. All s pectra reveal major a mounts of diphenylace tylene and no [2+2+2] cycl oaddition product of diphenylacetylene was formed.

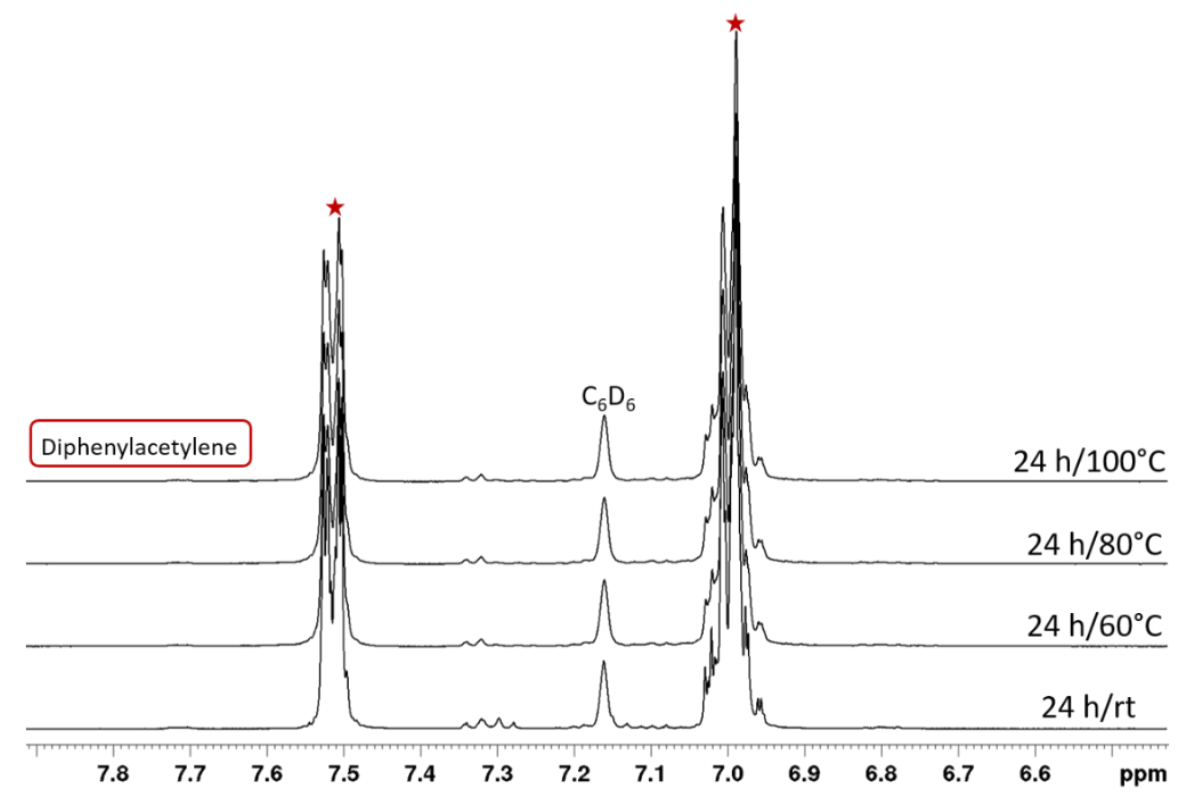

Figure S33: ${ }^{1} \mathrm{H}$ NMR spectra of the reaction of diphenyla cetyl ene with ca talytic a mounts of $\left[\left(\eta^{5}-\mathrm{C}_{5} \mathrm{H}_{5}\right) \mathrm{Co}\left(i \mathrm{Pr}_{2} I \mathrm{~m}\right)\left(\eta^{2}-\mathrm{C}_{2} \mathrm{H}_{4}\right)\right] \mathbf{1}$ $(5 \mathrm{~mol} \%)$ in $\mathrm{C}_{6} \mathrm{D}_{6}$ at different temperatures, depicted is the a romatic region of the ${ }^{1} \mathrm{H} N \mathrm{NMR}$ spectra. Only the resonances of diphenylacetylene (red) were detected, even at high temperatures $\left(100^{\circ} \mathrm{C}\right)$. This result has been confirmed by ${ }^{13} \mathrm{C}\left\{{ }^{1} \mathrm{H}\right\} \mathrm{NMR}$ spectroscopy and GC/MS analyses; the latter indicates only tra ces of hexaphenylbenzene (534.23), beside a major a mount of diphenylacetylene (278.2). 


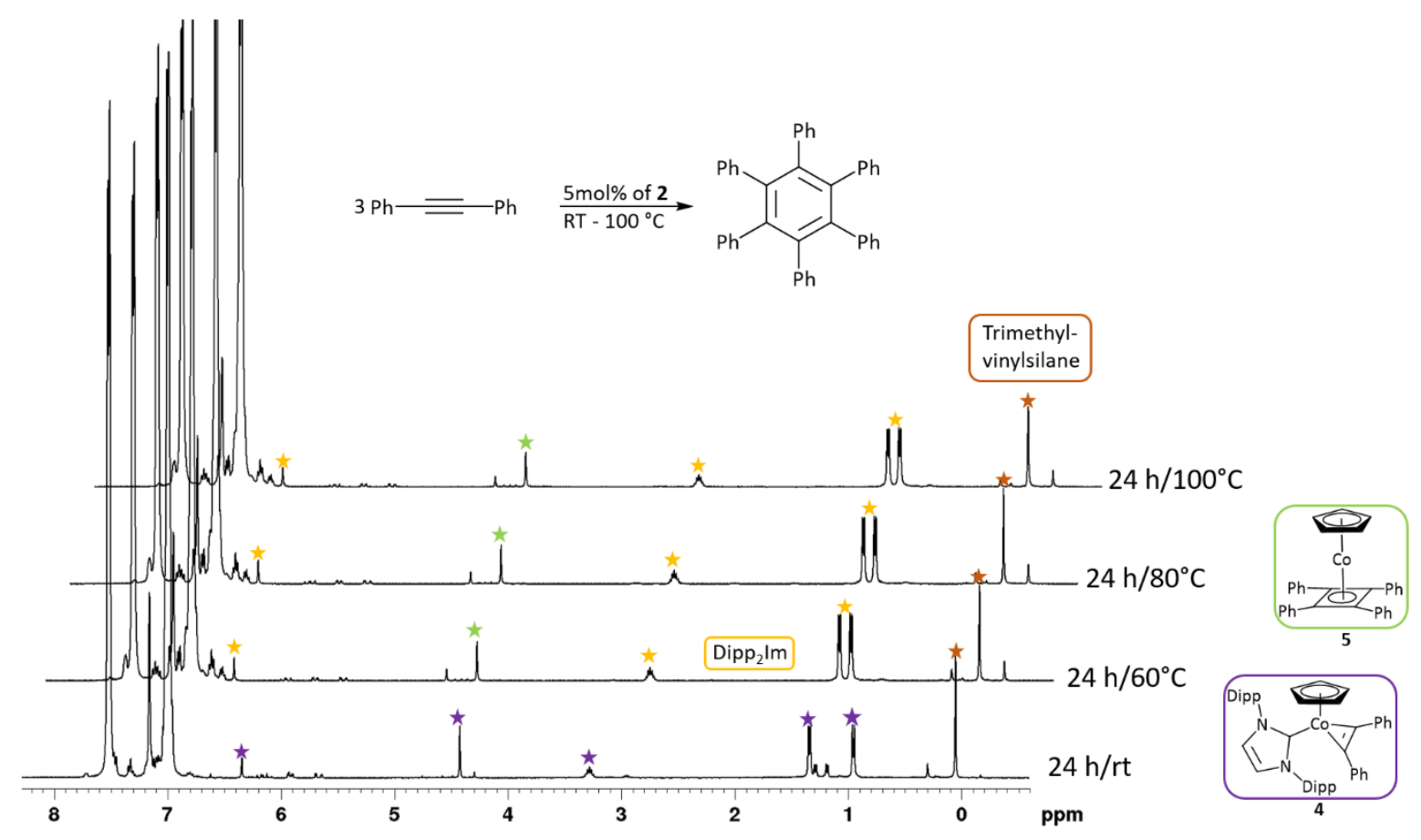

Figure S34: ${ }^{1} \mathrm{H}$ NMR spectra of the reaction of diphenylacetylene with ca talytic a mounts of $\left[\left(\eta^{5}-\mathrm{C}_{5} \mathrm{H}_{5}\right) \mathrm{Co}\left(\mathrm{Dipp}_{2} \mathrm{Im}\right)\left(\eta^{2}-\mathrm{C}_{2} \mathrm{H}_{3} \mathrm{SiMe} \mathrm{e}_{3}\right)\right]$ $2(5 \mathrm{~mol} \%)$ in $\mathrm{C}_{6} \mathrm{D}_{6}$ at different temperatures. ${ }^{1} \mathrm{H}$ NMR spectra at different temperatures of catalytically inves tigations of 2 $(5 \mathrm{~mol} \%)$ in intermolecular [2+2+2] cycl oaddition reaction of diphenyla cetylene in $\mathrm{C}_{6} \mathrm{D}_{6}$. The spectrum at room temperature reveals the resonances detected for $\left[\left(\eta^{5}-C_{5} H_{5}\right) \mathrm{Co}\left(\mathrm{R}_{2}^{1} \mathrm{Im}\right)\left(\eta^{2}-\mathrm{C}_{2} \mathrm{Ph}_{2}\right)\right] \mathbf{4}$ (violet), the spectra at higher temperatures reveals the resonances detected for $\left[\left(\eta^{5}-\mathrm{C}_{5} \mathrm{H}_{5}\right) \mathrm{Co}\left(\eta^{4}-\mathrm{C}_{4} \mathrm{Ph}_{4}\right)\right] \mathbf{5}$ (green), along with uncoordinated Dipp $\mathrm{Im}$ (yellow).

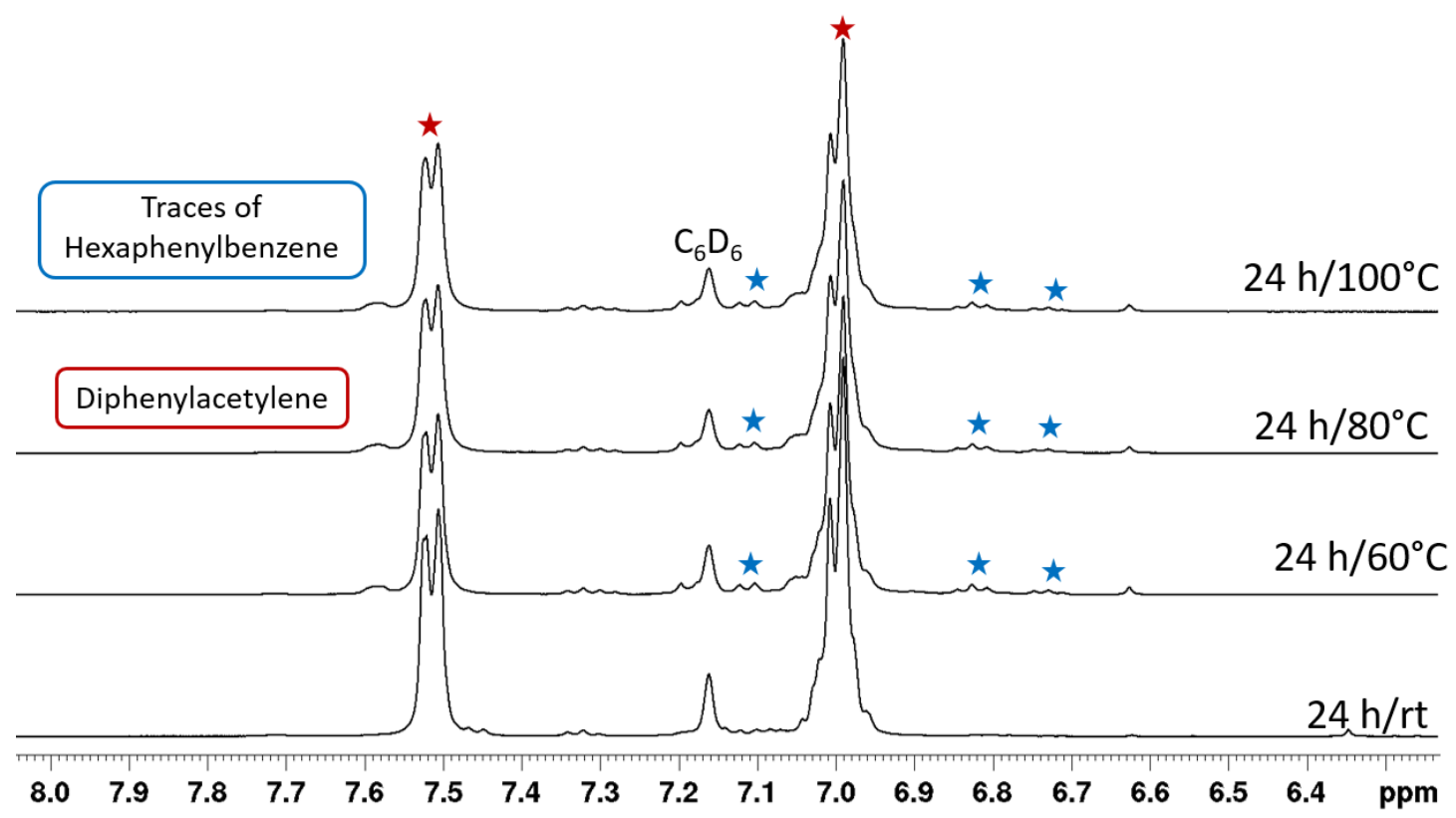

Figure S35: ${ }^{1} \mathrm{H}$ NMR spectra of the reaction of diphenylacetylene with ca talytic a mounts of $\left[\left(\eta^{5}-\mathrm{C}_{5} \mathrm{H}_{5}\right) \mathrm{Co}\left(\mathrm{Dipp}_{2} \mathrm{Im}\right)\left(\eta^{2}-\mathrm{C}_{2} \mathrm{H}_{3} \mathrm{SiMe} \mathrm{e}_{3}\right)\right]$ $2(5 \mathrm{~mol} \%)$ in $\mathrm{C}_{6} \mathrm{D}_{6}$ at different temperatures, shown is the aromatic region of the ${ }^{1} \mathrm{H}$ NMR spectra. Aside from signals of diphenylacetylene (red) signals for traces of hexaphenyl benzene (blue) at can be detected. Traces of hexaphenylbenzene (534.23) were also found in GC/MS analyses at $16.38 \mathrm{~min}$, beside a major amount of diphenylacetylene (278.2). 


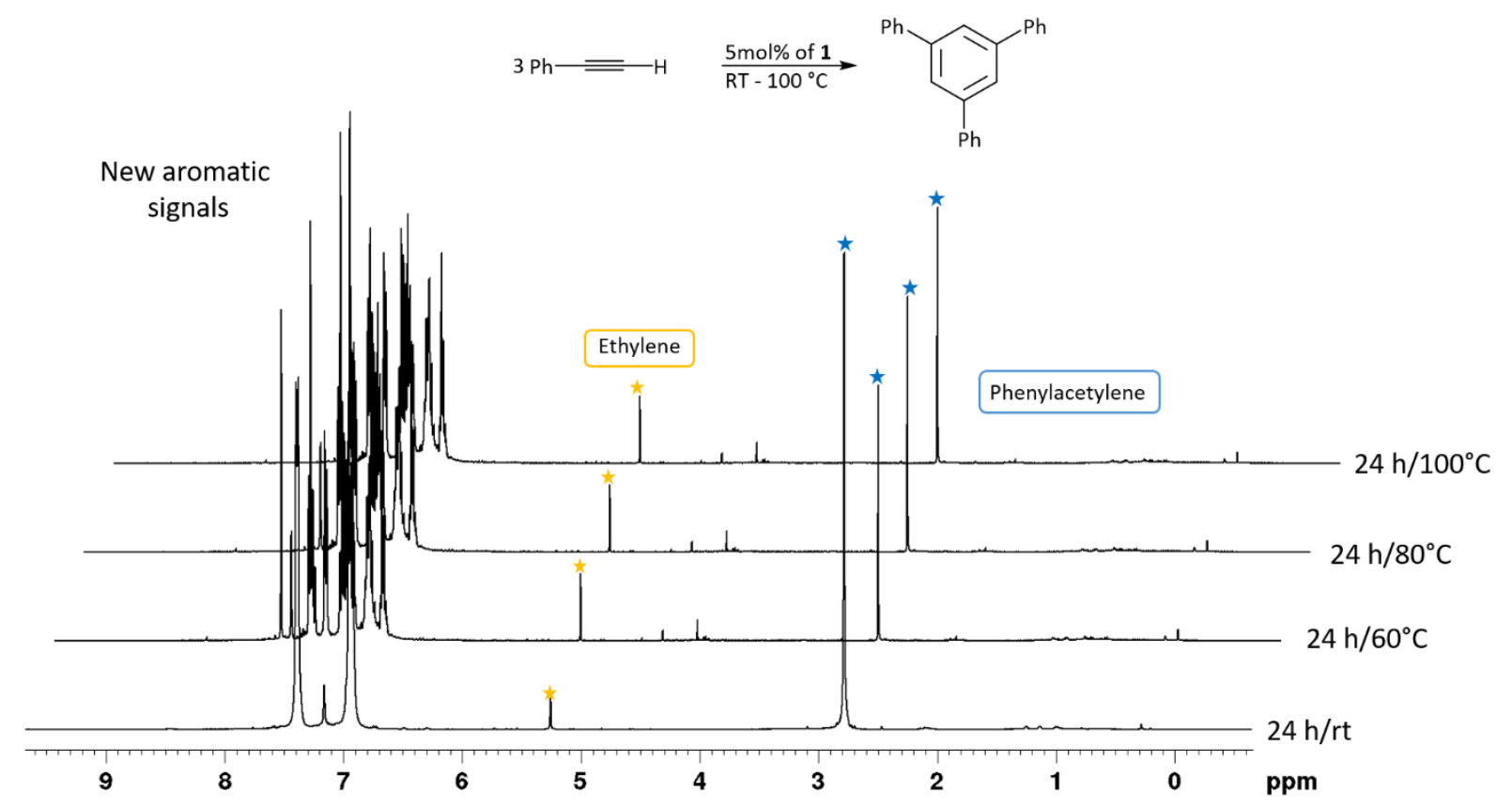

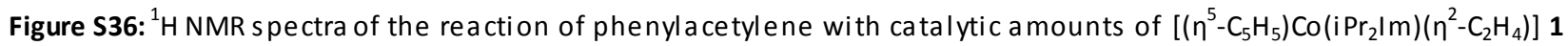
$(5 \mathrm{~mol} \%)$ in $\mathrm{C}_{6} \mathrm{D}_{6}$ at different te mperatures. The spectrum at room te mperature reveals a singlet for eliminated ethylene (yellow) and the signals of phenylacetylene (blue). After heating $\left(60^{\circ} \mathrm{C}\right)$, new resonances ca $\mathrm{n}$ be detected in the a romatic region along with resonances for traces of complex $\mathbf{8}$.

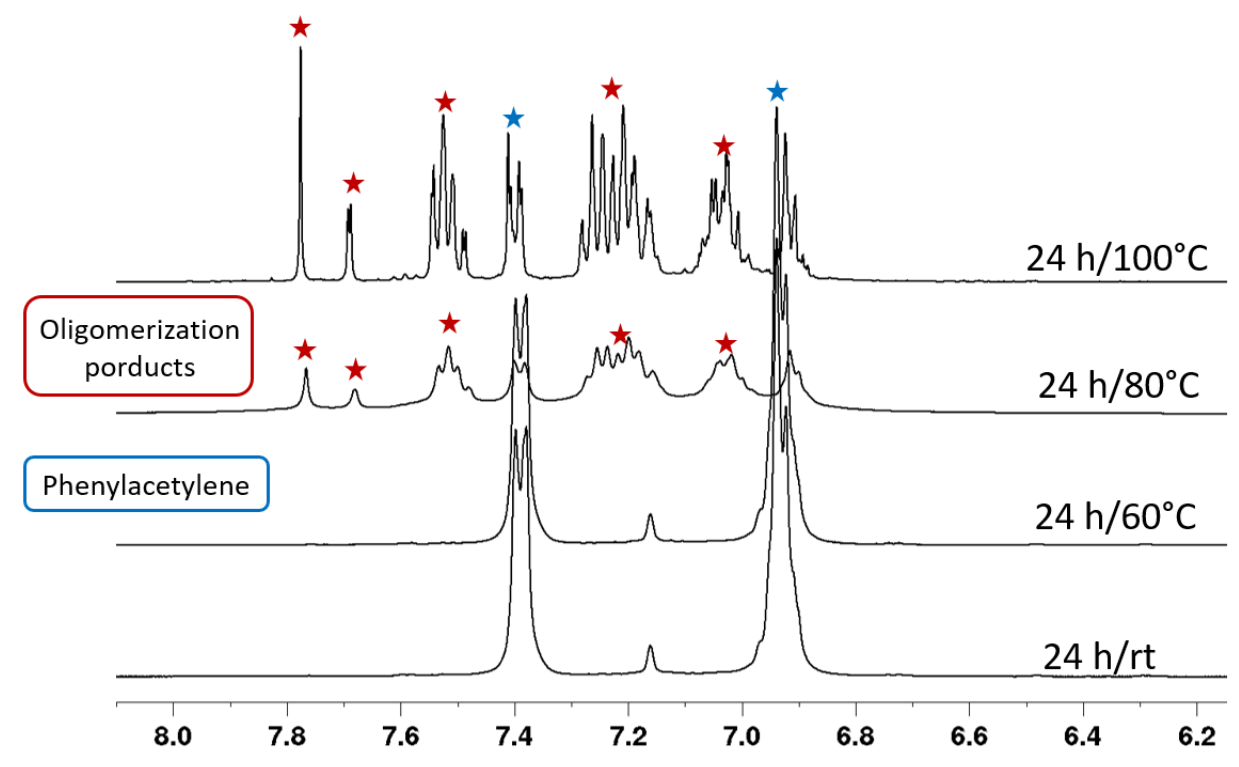

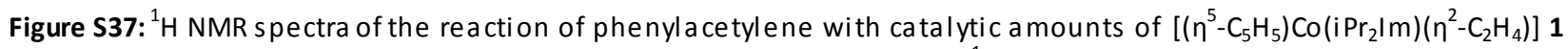
$(5 \mathrm{~mol} \%)$ in $\mathrm{C}_{6} \mathrm{D}_{6}$ at different te mperatures, shown is the aromatic region of the ${ }^{1} \mathrm{H}$ NMR spectra. At higher te mperatures $\left(80^{\circ} \mathrm{C}\right) \mathrm{a}$ set of new aromatic signals for different oligomerization products (red) was detected. GC/MS a nalys es reveal two different oligomerization products (306.1) at $2.94 \mathrm{~min}$ and $13.64 \mathrm{~min}$. But even after prolonged heating (e.g. $100{ }^{\circ} \mathrm{C}$ for $24 \mathrm{~h}$ ) the re were still significant a mounts of phenylacetyl ene (blue) detected in the NMR s pectra as well as in the GC/MS traces of the reaction. 


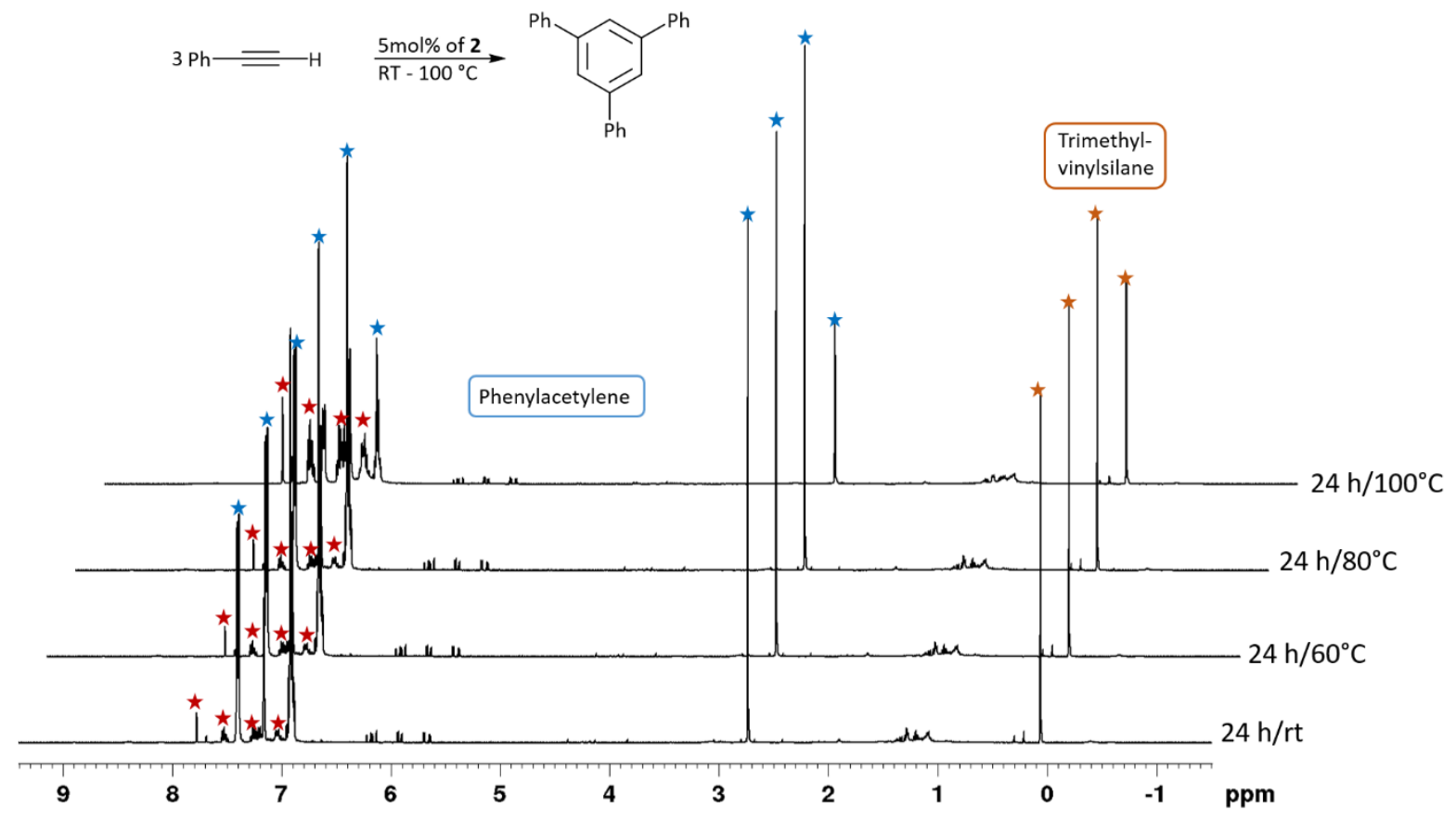

Figure S38: ${ }^{1} \mathrm{H}$ NMR spectra of the reaction of phenylacetylene with ca talytic a mounts of $\left[\left(\eta^{5}-\mathrm{C}_{5} \mathrm{H}_{5}\right) \mathrm{Co}\left(\mathrm{Dipp}_{2} \mathrm{Im}\right)\left(\eta^{2}-\mathrm{C}_{2} \mathrm{H}_{3} \mathrm{SiMe}_{3}\right)\right] 2$ $(5 \mathrm{~mol} \%)$ in $\mathrm{C}_{6} \mathrm{D}_{6}$ at different te mperatures. The spectra reveal the formation of new signals in the a romatic region (red) due to the formation of different $[2+2+2]$ cycl oaddition isomers, as well as the signals of phenyla cetylene (blue). The resonances of uncoordinated trimethyl vinyl silane (brown) are also detected.

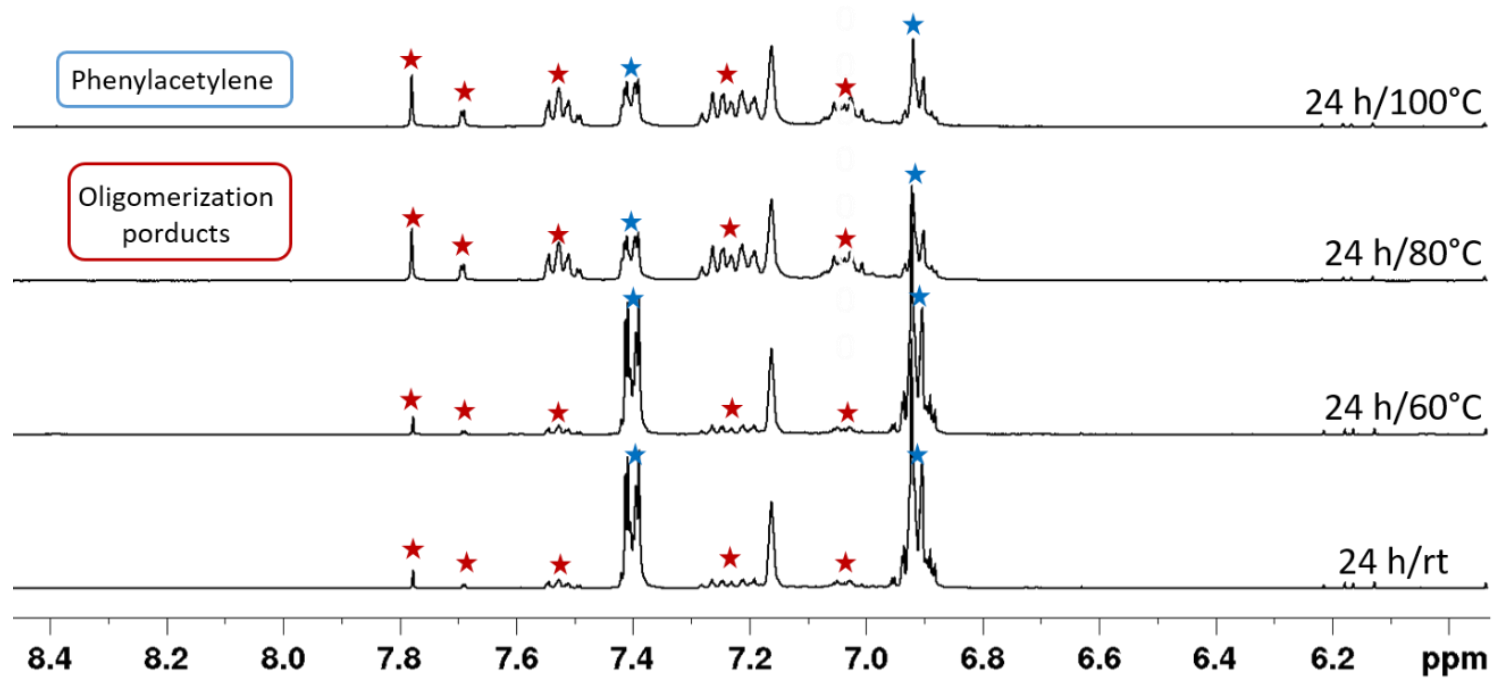

Figure S39: ${ }^{1} \mathrm{H}$ NMR spectra of the reaction of phenylacetylene with ca talytic a mounts of $\left[\left(\eta^{5}-\mathrm{C}_{5} \mathrm{H}_{5}\right) \mathrm{Co}\left(\mathrm{Dipp}_{2} \mathrm{Im}\right)\left(\eta^{2}-\mathrm{C}_{2} \mathrm{H}_{3} \mathrm{SiMe} \mathrm{e}_{3}\right)\right] 2$ $(5 \mathrm{~mol} \%)$ in $\mathrm{C}_{6} \mathrm{D}_{6}$ at different temperatures, shown is the aromatic region of the ${ }^{1} \mathrm{H}$ NMR spectra. The spectra reveal the formation of new signals in the a romatic region ( red) due to the formation of different [2+2+2] cycl oaddition isomers, as well as the signals of phenylacetylene (blue). According to GC/MS analysis are two different oligomerization products (306.1) at 2.94 min and $13.64 \mathrm{~min}$ formed. But even after prolonged heating (e.g. $100{ }^{\circ} \mathrm{C}$ for $24 \mathrm{~h}$ ) there were still significant amounts of phenylacetylene (blue) detected in the NMR spectra as well as in the GC/MS traces of the reaction. 


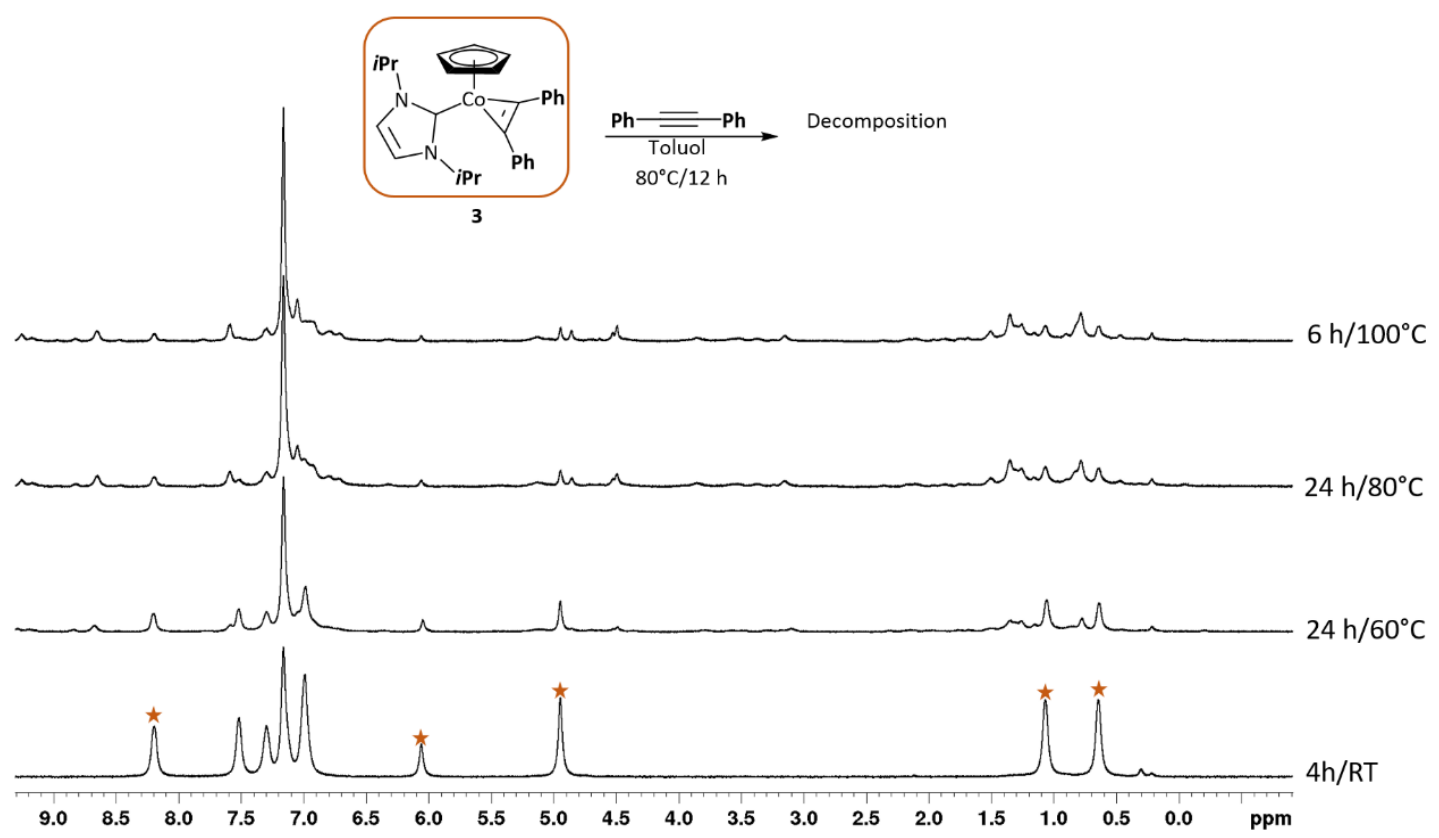

Figure S40: ${ }^{1} \mathrm{H}$ NMR spectra at different te mperatures of the reaction of $\left[\left(\eta^{5}-\mathrm{C}_{5} \mathrm{H}_{5}\right) \mathrm{Co}\left({ }^{\mathrm{i}} \mathrm{Pr}_{2} \mathrm{Im}\right)\left(\eta^{2}-\mathrm{C}_{2} \mathrm{Ph}_{2}\right)\right] 3$ with additional of diphenylacetylene in $\mathrm{C}_{6} \mathrm{D}_{6}$. The re is no reaction at room te mperature and the s pectrum reveals the resonances of 3 (brown) a nd diphenylacetylene. Applying higher temperatures leads to decomposition of 3.

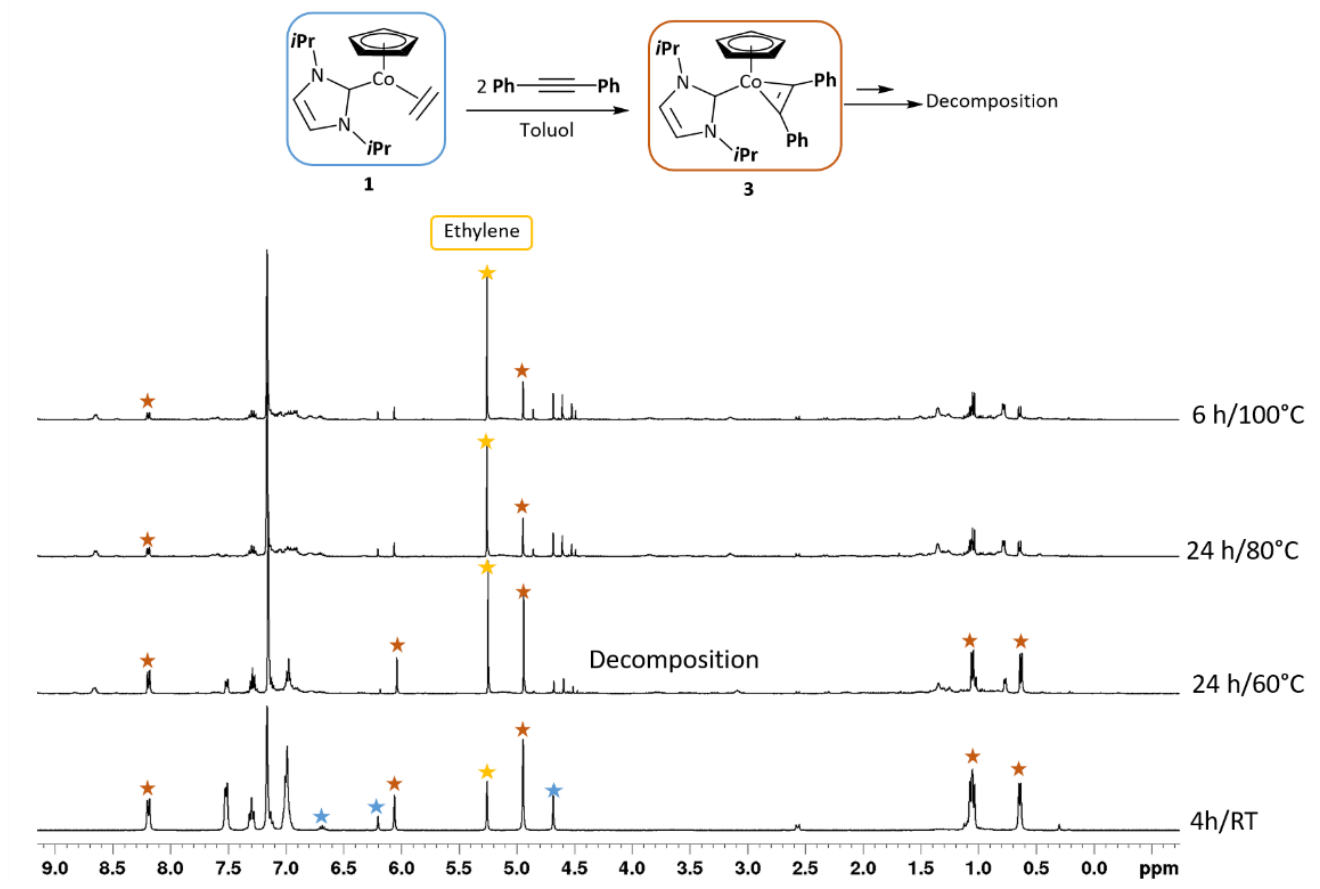

Figure S41: ${ }^{1} \mathrm{H}$ NMR spectra at different te mperatures of the reaction of $\left[\left(\eta^{5}-C_{5} \mathrm{H}_{5}\right) \mathrm{Co}\left({ }^{i} \mathrm{Pr}_{2} \mathrm{Im}\right)\left(\eta^{2}-\mathrm{C}_{2} \mathrm{H}_{4}\right)\right] 1$ with two equivalents of diphenylacetylene in $\mathrm{C}_{6} \mathrm{D}_{6}$. The NMR spectrum at room temperature reveals resonances for the complexes [ $\eta^{5}$ $\left.\left.\mathrm{C}_{5} \mathrm{H}_{5}\right) \mathrm{Co}\left({ }^{\prime} \mathrm{Pr}_{2} \mathrm{Im}\right)\left(\eta^{2}-\mathrm{C}_{2} \mathrm{H}_{4}\right)\right] \mathbf{1}$ (blue) and $\left[\left(\eta^{5}-\mathrm{C}_{5} \mathrm{H}_{5}\right) \mathrm{Co}\left({ }^{i} \mathrm{Pr}_{2} \mathrm{Im}\right)\left(\eta^{2}-\mathrm{C}_{2} \mathrm{Ph}_{2}\right)\right] \mathbf{3}$ (brown) and diphenylacetylene. At elevated temperatures the decomposition of $\mathbf{3}$ can be observed. 

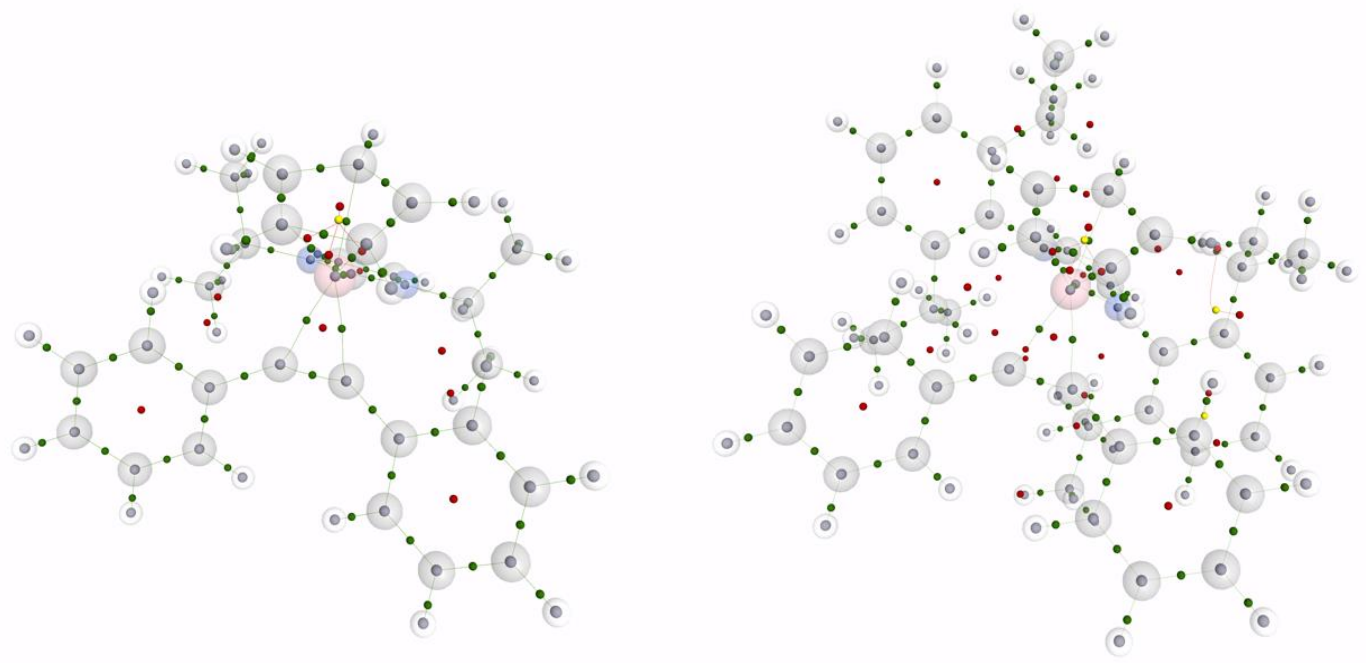

Figure S42: Bond critical (green) a nd ring critical (red) points calculated for $\left[\left(\eta^{5}-C_{5} H_{5}\right) C o\left({ }^{i} \operatorname{Pr}_{2} I m\right)\left(\eta^{2}-C_{2} P_{2}\right)\right]($ left $)$ a nd $\left[\left(\eta^{5}-\right.\right.$ $\left.\mathrm{C}_{5} \mathrm{H}_{5}\right) \mathrm{Co}\left(\right.$ Dipp $\left.\left._{2} \mathrm{Im}\right)\left(\eta^{2}-\mathrm{C}_{2} \mathrm{Ph}_{2}\right)\right]$ (right).

\section{Computational details - Optimized}

Geometries
$\left[\left(\eta^{5}-\mathrm{C}_{5} \mathrm{H}_{5}\right) \mathrm{Co}\left({ }^{\mathrm{i}} \mathrm{Pr}_{2} \mathrm{Im}\right)\left(\eta^{2}-\mathrm{C}_{2} \mathrm{Ph}_{2}\right)\right]$
Energy $=-2578.65598425711$
$N I M A G=0$
Co $\quad 6.9825518 \quad 8.1960871 \quad 1.5512654$
C $8.72829897 .4622564 \quad 1.4869162$
C $\quad 6.1412695 \quad 6.5600680 \quad 2.2081993$
C $\quad 6.1437588 \quad 6.54996810 .9088950$
C $\quad 5.5140474 \quad 9.6241266 \quad 0.8887286$
C $\quad 5.5493776 \quad 9.5981091 \quad 2.3176990$
C $\quad 6.8605135 \quad 9.9550978 \quad 2.7463188$
C $7.6424634 \quad 10.1671836 \quad 1.5614807$
C $\quad 6.8031085 \quad 9.9932486 \quad 0.4096036$
N $\quad 9.5441070 \quad 7.1045306 \quad 2.5371112$
$\begin{array}{llll}N & 9.5005461 & 7.1963326 & 0.3775025\end{array}$
C $\quad 5.6439224 \quad 5.9656133 \quad 3.4221447$
C $5.7249779 \quad 5.9180042-0.3132961$
H $\quad 4.64608399 .3862499 \quad 0.2801785$
H $\quad 4.7131385 \quad 9.3371543 \quad 2.9600865$
H $\quad 7.1972035 \quad 10.0838101 \quad 3.7708221$

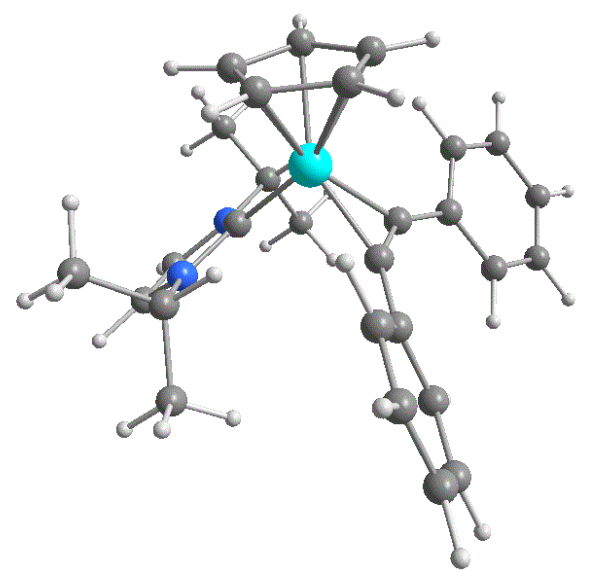



H $\quad 8.6901007 \quad 10.4577993 \quad 1.5413268$
H $\quad 7.0892272 \quad 10.1556012-0.6254511$
C $\quad 10.7739699 \quad 6.6426234 \quad 2.0906923$
C $9.1761829 \quad 7.2086012 \quad 3.9606851$
C $10.7467576 \quad 6.7009578 \quad 0.7333800$
C $9.07763667 .4227123-1.0167362$
C $\quad 5.1966960 \quad 4.6210090 \quad 3.4564089$
C $\quad 5.5693787 \quad 6.7037389 \quad 4.6259926$
C $5.4536535 \quad 6.6747084-1.4774352$
C $5.57435714 .5114581-0.4026563$
H $\quad 11.5547035 \quad 6.3071751 \quad 2.7616921$
H $\quad 8.1308325 \quad 7.5473280 \quad 3.9289424$
C $9.2446988 \quad 5.8427987 \quad 4.6462735$
C $10.0316378 \quad 8.2640805 \quad 4.6675765$
$\begin{array}{llll}\text { H } & 11.4995990 & 6.4257916 & 0.0055287\end{array}$
H $8.0245465 \quad 7.7236714 \quad-0.9191930$
C $9.16223316 .1319899-1.8333703$
C $9.87744968 .5670299-1.6469852$
H $\quad 5.2393770 \quad 4.0263129 \quad 2.5440594$
C $4.6998637 \quad 4.0557516 \quad 4.6279202$
C $\quad 5.0661887 \quad 6.1363324 \quad 5.7954807$
H $\quad 5.9048162 \quad 7.74164594 .6171927$
H $5.57564997 .7576302 \quad-1.4306350$
C $5.0250899 \quad 6.0643274-2.6542803$
C $5.1584723 \quad 3.9040456-1.5853527$
H $\quad 5.8053611 \quad 3.89923310 .4694792$
H $\quad 8.6168844 \quad 5.1105594 \quad 4.1229893$
H $8.8781015 \quad 5.9275356 \quad 5.6780911$
H $\quad 10.2753164 \quad 5.4585433 \quad 4.6871588$
H $\quad 9.9566928 \quad 9.2364065 \quad 4.1624489$
H $\quad 11.0924503 \quad 7.97270394 .6976120$
H $\quad 9.6906513 \quad 8.3869782 \quad 5.7049768$
H $8.5779913 \quad 5.3308312-1.3632306$
H $\quad \begin{array}{lll}10.2018702 & 5.7898657 & -1.9497366\end{array}$
H $\quad 8.75340996 .3036746 \quad-2.8381433$ 

H $\quad 9.7916921 \quad 9.4849427 \quad-1.0502892$
H $\quad 9.4990545 \quad 8.7756160 \quad-2.6574074$
H $\quad 10.9445518 \quad 8.3129127 \quad-1.7358132$
H $\quad 4.3612205 \quad 3.0178929 \quad 4.6226794$
C $4.6302748 \quad 4.8075750 \quad 5.8070765$
$\begin{array}{llll}H & 5.0120559 & 6.7356233 & 6.7064807\end{array}$
H $\quad 4.8077020 \quad 6.6769046 \quad-3.5314679$
C $\quad 4.8751494 \quad 4.6746382 \quad-2.7188699$
H $\quad 5.0533232 \quad 2.8180815 \quad-1.6242036$
H $\quad 4.2410836 \quad 4.3616175 \quad 6.7233007$
H $4.54632594 .1967930 \quad-3.6425939$

\section{$\left[\left(\eta^{5}-C_{5} H_{5}\right) C o\left(D_{i p p} I m\right)\left(\eta^{2}-C_{2} P h_{2}\right)\right]$}
Energy $=-3276.858758454$
NIMAG $=0$
Co $\quad 6.9053609 \quad 8.0107351 \quad 1.3919782$
C 8.74886097 .53380851 .3900549
C $6.1272595 \quad 6.5326952 \quad 2.4032053$
C $\quad 6.0954820 \quad 6.2417959 \quad 1.1362091$
C $5.2982549 \quad 9.1084122 \quad 0.4437921$
C $\quad 5.2674471 \quad 9.3182131 \quad 1.8583680$
C $6.4946213 \quad 9.9180391 \quad 2.2549541$
C $7.2999324 \quad 10.0286262 \quad 1.0771421$
C $\quad 6.5491904 \quad 9.5550196 \quad-0.0553789$
N $\quad 9.5815409 \quad 7.2657419 \quad 2.4736282$
$\begin{array}{llll}\text { N } & 9.6601391 & 7.5927504 & 0.3308510\end{array}$
C $\quad 5.5031974 \quad 6.2912111 \quad 3.6831247$
C $\quad 5.5106775 \quad 5.4230368 \quad 0.1079572$
H $\quad 4.4985208 \quad 8.6578596 \quad-0.1362501$
$\begin{array}{llll}H & 4.4502361 & 9.0418453 & 2.5183563\end{array}$
H $\quad 6.7588751 \quad 10.2543531 \quad 3.2508451$
H $8.2966449 \quad 10.4571136 \quad 1.0427820$
H $\quad 6.87340849 .5496974 \quad-1.0908299$
C $10.9213142 \quad 7.1984275 \quad 2.0983340$
C $10.9703837 \quad 7.4086545 \quad 0.7637548$

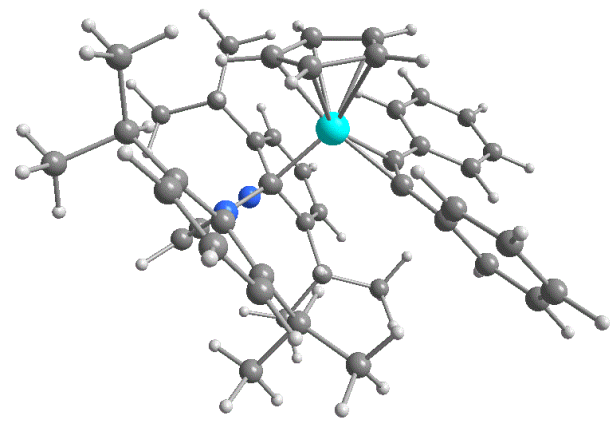



C $\quad 4.6336824 \quad 5.1888127 \quad 3.8774865$
C $\quad 5.6832308 \quad 7.1761613 \quad 4.7673885$
C $5.1952705 \quad 5.9544559-1.1643473$
C $\quad 5.17814694 .0655983 \quad 0.3463365$
H $\quad 11.7057766 \quad 6.9996633 \quad 2.8165549$
$\begin{array}{llll}\text { H } & 11.8082051 & 7.4309708 & 0.0796735\end{array}$
H $\quad 4.4583924 \quad 4.4990533 \quad 3.0517068$
C $\quad 3.9801143 \quad 4.9926475 \quad 5.0914191$
C $5.0283990 \quad 6.9762765 \quad 5.9816486$
H $\quad 6.3526639 \quad 8.0249429 \quad 4.6306899$
H $\quad 5.4892947 \quad 6.9802288$-1.3840877
C $4.5234333 \quad 5.1930009-2.1192345$
C $4.52638363 .3022303 \quad-0.6193719$
H $\quad 5.4474008 \quad 3.6156424 \quad 1.3025928$
H $\quad 3.3084485 \quad 4.1400410 \quad 5.2093189$
C $4.1734530 \quad 5.8836415 \quad 6.1541081$
H $\quad 5.1873163 \quad 7.6786459 \quad 6.8020841$
H $\quad 4.2751859 \quad 5.6381229 \quad-3.0847424$
C $4.1804947 \quad 3.8626871 \quad-1.8547839$
H $\quad 4.2811462 \quad 2.2599791-0.4058710$
H $\quad 3.6609851 \quad 5.7272244 \quad 7.1044485$
H $3.6610801 \quad 3.2657323 \quad-2.6054830$
C $9.2460476 \quad 7.0147106 \quad 3.8606693$
C $9.2988679 \quad 8.08338324 .7832696$
C $9.05696265 .6761702 \quad 4.2716203$
C $9.1257187 \quad 7.7801223 \quad 6.1406969$
C $8.8837649 \quad 5.4345387 \quad 5.6411274$
C $8.9178733 \quad 6.47140316 .5682866$
H $\quad 9.1559781 \quad 8.5845920 \quad 6.8761502$
H $\quad 8.7208467 \quad 4.4131084 \quad 5.9855568$
H $\quad 8.7808695 \quad 6.2590972 \quad 7.6296931$
C $9.3877530 \quad 7.7234674 \quad-1.0864265$
C $9.0330069 \quad 6.5646174 \quad-1.8217473$
C $9.6267168 \quad 8.9642247 \quad-1.7202206$
C $8.7900579 \quad 6.7193870 \quad-3.1928650$ 

C $\quad 9.3788390 \quad 9.0539418 \quad-3.0982048$
C $8.94018927 .9524031-3.8246063$
H $\quad 8.48779515 .8529989-3.7796169$
H $9.5395708 \quad 10.0045489$-3.6081801
H $\quad 8.7398195 \quad 8.0460713 \quad-4.8932345$
C $9.5878202 \quad 9.5183060 \quad 4.3566756$
$\begin{array}{llll}H & 9.2947285 & 9.6094779 & 3.3003818\end{array}$
C $8.7845841 \quad 10.5570020 \quad 5.1579083$
H $\quad 8.8842902 \quad 11.5493363 \quad 4.6952718$
H $\quad 7.7162021 \quad 10.3063657 \quad 5.2042347$
H $\quad 9.1508147 \quad 10.6449345 \quad 6.1914692$
C $11.09254279 .8412957 \quad 4.4655482$
H $\quad 11.2858721 \quad 10.8788558 \quad 4.1543050$
H $\quad 11.4377246 \quad 9.7295526 \quad 5.5044377$
H $\quad 11.7010527 \quad 9.1820310 \quad 3.8331967$
C $9.1063982 \quad 4.5052158 \quad 3.2965704$
H $\quad 8.9051994 \quad 4.9020015 \quad 2.2909597$
C $\quad 10.5089626 \quad 3.8620957 \quad 3.2905176$
H $\quad 10.5443164 \quad 3.0273128 \quad 2.5749405$
H $\quad 11.2910463 \quad 4.5798004 \quad 3.0093093$
H $\quad 10.7564823 \quad 3.4644848 \quad 4.2865250$
C $8.0443942 \quad 3.4328202 \quad 3.5857941$
H $\quad 8.0352506 \quad 2.6916194 \quad 2.7736083$
$\begin{array}{llll}H & 8.2566632 & 2.8878251 & 4.5176767\end{array}$
H $\quad 7.0418434 \quad 3.8708240 \quad 3.6682011$
$\begin{array}{llll}\text { C } & 9.0138914 & 5.1721617 & -1.1953937\end{array}$
H $\quad 8.5912715 \quad 5.2694511 \quad-0.1829736$
C $8.1639354 \quad 4.1508372 \quad-1.9633741$
H $\quad 8.6275524 \quad 3.8830274 \quad-2.9254676$
H $\quad 8.0866771 \quad 3.2255487 \quad-1.3761601$
H $\quad 7.1466741 \quad 4.5118633 \quad-2.1536797$
C $10.4499733 \quad 4.6128808-1.0765006$
H $\quad 10.9117247 \quad 4.5346646 \quad-2.0725783$
H $11.0971717 \quad 5.2341190 \quad-0.4464312$
H $\quad 10.4243429 \quad 3.6046100-0.6376083$ 

C $\quad 10.2272737 \quad 10.1672102 \quad-0.9989970$
H $\quad \begin{array}{lll}10.1428694 & 9.9886815 & 0.0828055\end{array}$
C $11.7294970 \quad 10.2936039-1.3309612$
H $11.875178810 .4778552-2.4056758$
H $\quad 12.1755695 \quad 11.1342415 \quad-0.7791204$
H $\quad 12.2875676 \quad 9.3839015-1.0715596$
C $9.5173603 \quad 11.4938282-1.3206561$
H $\quad 8.4366309 \quad 11.4399431 \quad-1.1387896$
H $\quad 9.9282297 \quad 12.3005199 \quad-0.6960808$
H $\quad 9.6699912 \quad 11.7888129 \quad-2.3690104$ 